\title{
CAMA
}

Centre for Applied Macroeconomic Analysis

\section{Global Banks, Financial Shocks and International Business Cycles: Evidence from an Estimated Model}

\section{CAMA Working Paper 30/2013 May 2013}

Robert Kollmann, ECARES, Université Libre de Bruxelles, CEPR and Centre for Applied Macroeconomic Analysis (CAMA), Australian National University

\begin{abstract}
This paper estimates a two-country model with a global bank, using US and Euro Area (EA) data, and Bayesian methods. The estimated model matches key US and EA business cycle statistics. Empirically, a model version with a bank capital requirement outperforms a structure without such a constraint. A loan loss originating in one country triggers a global output reduction. Banking shocks matter more for EA macro variables than for US real activity. Banking shocks account for about 3\%-5\% of the unconditional variance of US GDP and for 4\%-14\% of the variance of EA GDP. During the Great Recession (2007-09), banking shocks accounted for about $12 \%-20 \%$ of the fall in US and EA GDP, and for more than a third of the fall in EA investment and employment.
\end{abstract}




\section{Keywords}

financial crisis, global banking, real activity, investment, Bayesian econometrics

\section{JEL Classification}

F36, F37, E44, G21

\section{Address for correspondence:}

(E) cama.admin@anu.edu.au

The Centre for Applied Macroeconomic Analysis in the Crawford School of Public Policy has been established to build strong links between professional macroeconomists. It provides a forum for quality macroeconomic research and discussion of policy issues between academia, government and the private sector.

The Crawford School of Public Policy is the Australian National University's public policy school, serving and influencing Australia, Asia and the Pacific through advanced policy research, graduate and executive education, and policy impact. 


\title{
Global Banks, Financial Shocks and International Business Cycles: Evidence from an Estimated Model
}

\author{
Robert Kollmann ${ }^{(*)}$ \\ ECARES, Université Libre de Bruxelles, CEPR and CAMA
}

May 15, 2013

This paper estimates a two-country model with a global bank, using US and Euro Area (EA) data, and Bayesian methods. The estimated model matches key US and EA business cycle statistics. Empirically, a model version with a bank capital requirement outperforms a structure without such a constraint. A loan loss originating in one country triggers a global output reduction. Banking shocks matter more for EA macro variables than for US real activity. Banking shocks account for about 3\%-5\% of the unconditional variance of US GDP and for 4\%-14\% of the variance of EA GDP. During the Great Recession (200709), banking shocks accounted for about $12 \%-20 \%$ of the fall in US and EA GDP, and for more than a third of the fall in EA investment and employment.

Key words: financial crisis, global banking, real activity, investment, Bayesian econometrics.

JEL codes: F36, F37, E44, G21

(*) Address: R. Kollmann, ECARES, CP 114, Université Libre de Bruxelles; 50 Av. Franklin Roosevelt; B-1050 Brussels, Belgium; robert_kollmann@yahoo.com.

I am grateful to Ken West and to two referees, as well as to Alejandro Justiniano, Matthias Paustian, Werner Roeger and Raf Wouters for advice. Matthias Paustian contributed to this project at an early stage-I also thank him for computer code. Helpful suggestions were also received from Fabian Lipinsky, Giovanni Lombardo, Jochen Mankart, Olivier Pierrard, Gernot Müller, Alan Sutherland, Christoph Thoenissen, Skander Van den Heuvel, Egon Zakrajšek and participants at workshops at the SWIM, SED and AEA meetings, Bonn, St.Gallen, London Business School, Central Bank of Luxembourg, National Bank of Belgium, Bank of France and Bank of England. I thank Egon Zakrajšek for providing me with data on the excess bond premium, US business loans and loan capacity. 


\section{Introduction}

The recent financial crisis began in US financial markets in 2007 and was quickly and strongly transmitted to Europe and other parts of the world. The crisis revealed the fragility of major financial institutions, and led to the worst global recession since the Great Depression. These dramatic events require a rethinking of the role of financial intermediaries for real activity. Before the financial crisis, standard applied macro models abstracted from financial intermediaries (e.g., Christiano et al. (2005)). The crisis revealed the stark limitations of those models.

The crisis has stimulated much research that incorporates banks into dynamic stochastic general equilibrium (DSGE) models. Given the global nature of the banking industry, and of the financial crisis, that research has frequently focused on open economy models; see, for example, Devereux and Sutherland (2011), Kamber and Thoenissen (2011), Kollmann, Enders and Müller (2011), Perri and Quadrini (2011) and Van Wincoop (2011). Closed economy DSGE models with banks were, i.a., presented by Aikman and Paustian (2006), Van den Heuvel (2008), Gerali et al. (2010) and Meh and Moran (2010). ${ }^{1}$ In this new class of DSGE models, bank capital is a key state variable for the supply of credit, and for real activity; negative shocks to bank capital are predicted to increase the spread between banks' lending and deposit rates, and to trigger a fall in bank credit and output; with a globalized banking system, a loan loss in one country can thus lead to a worldwide recession.

So far, this new macro-banking literature has mainly used calibrated models-a systematic empirical evaluation, using econometric methods, is necessary, to guide further model building and policy. In order to provide an empirical assessment of the role of banks as a source of shocks and as a transmission channel in the global economy, the paper here estimates (using Bayesian methods) a two-country DSGE model with a global bank. Quarterly US and Euro Area (EA) macro data and banking data (bank loans, bank

\footnotetext{
${ }^{1}$ Other open economy models with banks can be found in Correa et al. (2010), Davis (2010), Nguyen (2011), Andreasen et al. (2010), Ueda (2011), Dedola and Lombardo (2012) and Lipinsky (2012), while closed economy DSGE models with banks were also presented by Brunnermeier and Sannikov (2010), de Walque et al. (2010), Gertler and Karadi (2011), Gertler and Kiyotaki (2011), Iacoviello (2010), Del Negro et al. (2011), He and Krishnamurthy (2012), Dewachter and Wouters (2012) and Kollmann et al. (2012).
} 
capital ratio, loan spread) for the period 1990q1-2010q3 are used. ${ }^{2}$ Specifically, I take the Kollmann, Enders and Müller (2011) two-country model with a banking sector to the data - that structure is used as it features a 'bank capital channel' that is broadly representative of those in other recent macro-banking models. The structure builds on the International Real Business Cycle (RBC) literature, but while standard International RBC models assume direct frictionless international borrowing and lending (e.g., Backus et al. (1992), Baxter and Crucini (1995), Kollmann (1996)), the model here assumes that a global bank intermediates between savers and borrowers in the two countries. Importantly, the bank has to finance a fraction of her assets using equity (own funds). This capital requirement can reflect legal constraints and, more broadly, market pressures. It implies that the loan rate spread (relative to the deposit rate) is a decreasing function of bank capital.

The estimated model assumes demand and supply shocks in home and foreign labor and good markets. In addition, there are stochastic loan losses (defaults) in the two countries, and shocks to the required (target) bank capital ratio-henceforth, I refer to these shocks as 'banking shocks'.

The estimation results suggest that the bank capital requirement, and the banking shocks, matter for the dynamics of macro and banking variables. A model with these ingredients outperforms a model variant without an operative bank capital requirement (and without banking shocks)--the model with the bank capital requirement generates predicted second moments of key macro and banking variables that are closer to empirical moments (the marginal likelihood of that model is markedly higher).

In the presence of a bank capital requirement, banking shocks induce synchronized responses of Home and Foreign real activity. That positive international transmission mechanism is not present in standard International RBC models (without banks). According to baseline model estimates, a one percentage point fall in the global bank capital ratio raises the loan rate spread by about 20 basis points. An unanticipated US loan loss worth $1 \%$ of steady state GDP lowers US and EA GDP by about $0.10 \%$ and

\footnotetext{
${ }^{2}$ Some previous papers have estimated open economy DSGE models without banks; two-country models were estimated by de Walque et al. (2005), Rabanal and Tuesta (2006) and Le et al. (2010) who also used UE and EA data, and by Jacob and Peersman (2011). Small open economy models were estimated by Adolfson et al. (2009) and Justiniano and Preston (2010).
} 
0.12\%, respectively, on impact; a EA loan loss of equal size lowers US and EA GDP by $0.14 \%$ and $0.18 \%$, respectively. A US loan loss thus lowers EA real activity more than US real activity. An unanticipated increase in the required bank ratio by one percentage point lowers US and EA GDP by $0.10 \%$ and $0.11 \%$, respectively, on impact.

The estimated banking model matches key cyclical properties of US and EA macro and banking variables. In particular, it captures the fact that US and EA loans are procyclical, while the loan spread is countercyclical. However, in the banking model here--as in standard International RBC models (without banks)--a positive shock to home TFP raises home GDP, but lowers foreign GDP. Like standard International RBC models, the present model can only capture the high cross-country correlations of real activity seen in the data, if TFP and other 'non-banking' shocks are highly positively correlated across countries.

In most model variants considered in this paper, banking shocks account for a non-negligible share of the variance of real activity. Specifically, banking shocks explain about $3 \%-5 \%$ of the variance of US GDP, and $4 \%-14 \%$ of the variance of EA GDP. The variance share of investment accounted for by banking shocks is higher, especially for EA investment (above 20\%). Thus, banking shocks matter more for EA real activity than for US real activity. US loan losses account for a greater share of the variance of EA real activity than of the variance of US real activity. Exposure to US loan losses (via the global banking system) thus deepened the recent recession in the EA.

Banking shocks contributed noticeably to the 'Great Recession' of 2007-09, but were not its dominant cause: banking shocks accounted for about $12 \%-20 \%$ of the fall in US and EA GDP during the recession--but they accounted for more than a third of the fall in EA investment and employment. During the previous two US recessions in the estimation period (1990-91 and 2001), banking shocks accounted for a roughly similar share of the fall in US output, investment and employment as in the 2007-09 recession.

I consider several empirical measures of credit and lending spreads and find that the key results are robust across the different measures.

This paper is complementary to Gerali et al. (2010) who estimated (using Euro Area data) a closed economy New Keynesian macro model with a banking sector that faces a bank capital requirement. The paper here differs (inter alia) from Gerali et al. by considering a real (flex-price) two-country world with a global bank that experiences loan 
loss shocks and shocks to her required capital ratio. By contrast, the empirical analysis of Gerali et al. focuses on the role of shocks to bank mark-ups and to borrowers' collateral constraints (these authors do not consider loan loss shocks or shocks to the required bank capital ratio).

Section 2 presents the model. Section 3 discusses the econometric approach. Section 4 describes key data features. Section 5 reports the estimation results. Section 6 concludes.

\section{A two-country world with a global financial intermediary}

As mentioned above, this paper takes the theoretical two-country model of Kollmann et al. (2011) to US and EA data. ${ }^{3}$ In each of the two countries, called 'Home' $(\mathrm{H})$ and 'Foreign' (F), there is a representative worker, an entrepreneur and a government. A global bank collects deposits from workers, and makes loans to entrepreneurs, in both countries. The bank faces a capital requirement: a fraction of bank assets has to be financed using the bank's own funds (equity). Entrepreneurs produce a homogenous tradable good that is used for consumption and for capital accumulation. All agents are infinitely-lived. Markets are competitive. Preferences and technologies have the same structure in both countries. The following exposition focuses thus on the Home country. Foreign variables are denoted by an asterisk.

\subsection{Preferences, technologies, markets}

\section{The Home worker}

The Home worker provides labor to the Home entrepreneur and invests her savings in one-period bank deposits. Her date $t$ budget constraint is:

$$
C_{t}^{S}+D_{t+1}+T_{t}^{S}=\omega_{t} N_{t}+D_{t} R_{t}^{D},
$$

where $C_{t}^{S}$ and $N_{t}$ are the worker's consumption and hours worked respectively. $\omega_{t}$ is the real wage rate. $D_{t+1}$ is the bank deposit held by the saver at the end of period $t . R_{t}^{D}$ is

\footnotetext{
${ }^{3}$ Governments, and a rich set of (banking and non-banking) shocks are added to the structure in Kollmann et al. (2011), in order to permit an empirical evaluation of the bank capital channel, and provide estimates of the contribution of banking shocks to historical time series for key macro aggregates. Also, the present paper allows for asymmetries between countries, in order to capture differences between the sensitivity of the US and EA economies to banking shocks.
} 
the gross interest rate on deposits, between $t-1$ and $t$. $T_{t}^{S}$ is a lump sum tax. The worker's date $t$ expected life-time utility, $V_{t}^{S}$, is:

$$
V_{t}^{S}=u\left(C_{t}^{S}\right)+\Psi^{D} u\left(D_{t+1}\right)-\Psi_{t}^{N} N_{t}+E_{t} \beta_{t+1}^{S} V_{t+1}^{S},
$$

with $u(x)=\frac{1}{1-\sigma}\left(x^{1-\sigma}-1\right), \quad \sigma>0$ and $\Psi^{D}>0$. The worker's marginal disutility of labor, $\Psi_{t}^{N}>0$, is an exogenous random variable. $\Psi_{t}^{N}$ will be referred to as the Home labor supply shock. Note that deposits provide utility to the worker (liquidity services). This ensures that, in equilibrium, the deposit rate is smaller than the loan rate, and that workers hold deposits while entrepreneurs borrow. The worker's subjective discount factor is decreasing in her future consumption: $\beta_{t+1}^{S} \equiv \beta^{S}\left(\overline{C_{t+1}^{S}}\right)$, with $0<\beta^{S}\left(\overline{C_{t+1}^{S}}\right)<1, \quad \beta^{S_{1}}\left(\overline{C_{t+1}^{S}}\right)<0$. The subjective discount factors of other agents are likewise decreasing functions of their own consumption. ${ }^{4}$ Agents treat their subjective discount factors as given, i.e. they do not internalize the effect of consumption on the discount factor-I thus write the argument of the subjective discount factor with an upper-bar. It is assumed that all agents have the same steady state rate of time preference, and the same risk aversion coefficient, $\sigma$.

The Home worker maximizes her life-time utility subject to the period-by-budget constraint (1). That decision problem has these first-order conditions:

$$
\begin{gathered}
u^{\prime}\left(C_{t}^{S}\right) \omega_{t}=\Psi_{t}^{N}, \\
R_{t+1}^{D} E_{t} \beta_{t+1}^{S} u^{\prime}\left(C_{t+1}^{S}\right) / u^{\prime}\left(C_{t}^{S}\right)+\Psi^{D} u^{\prime}\left(D_{t+1}\right) / u^{\prime}\left(C_{t}^{S}\right)=1 .
\end{gathered}
$$

\section{The Home entrepreneur}

The Home entrepreneur accumulates physical capital and uses capital and local labor to produce output. Her technology is $Z_{t}=\theta_{t}\left(K_{t}\right)^{\alpha}\left(N_{t}\right)^{1-\alpha}, 0<\alpha<1$, where $Z_{t}, K_{t}$ and $N_{t}$ are output, capital and labor, respectively. Total factor productivity (TFP), $\theta_{t}>0$, is an exogenous random variable. The law of motion of the capital stock is $K_{t+1}=(1-\delta) K_{t}+\Xi_{t} I_{t}$, where $0 \leq \delta \leq 1$ is the capital depreciation rate and $I_{t}$ is gross investment. $\Xi_{t}>0$ is an exogenous random shock to investment efficiency (Fischer (2006), Justiniano et al.

\footnotetext{
${ }^{4}$ The endogenous discount factors induce mean-reversion in individual wealth, and thus ensures stationarity (Kollmann (1991); Schmitt-Grohé and Uribe (2003)). The numerical solution method (local approximation) and the estimation method require stationarity.
} 
(2008)). Gross investment is generated using output. Let $I \xi\left(I_{t} / I\right)$ be the amount of output needed to generate $I_{t}$, where $I$ is steady state investment, and $\xi$ is an increasing, strictly convex function with $\xi(1)=\xi^{\prime}(1)=1$. Henceforth, variables without time subscripts denote steady state values. The Home entrepreneur's period $t$ budget constraint is:

$$
L_{t} R_{t}^{L}-\Delta_{t}+\mathrm{I} \xi\left(I_{t} / I\right)+\omega_{t} N_{t}+d_{t}^{E}+T_{t}^{E}=L_{t+1}+\theta_{t}\left(K_{t}\right)^{\alpha}\left(N_{t}\right)^{1-\alpha},
$$

where $L_{t}$ is a one-period bank loan received by the Home entrepreneur in period $t-1 . R_{t}^{L}$ is the gross interest rate on that loan, set at $t-1$. In period t, the Home entrepreneur defaults by an exogenous random amount $\Delta_{t}$ on the amount $L_{t} R_{t}^{L}$ that she owes the bank. $T_{t}^{E}$ is a lump sum tax. $d_{t}^{E}$ is the entrepreneur's dividend income at $t$. The entrepreneur consumes her dividend income. Her expected lifetime utility at $t, V_{t}^{E}$, is: $V_{t}^{E}=u\left(d_{t}^{E}\right)+E_{t} \beta_{t+1}^{E} V_{t}^{E}$, with $\beta_{t+1}^{E}=\beta^{E}\left(\overline{d_{t+1}^{E}}\right)<1$. Utility maximization by the entrepreneur (subject to (4)) yields these first-order conditions:

$$
\begin{gathered}
\omega_{t}=(1-\alpha) \theta_{t} K_{t}^{\alpha} N_{t}^{-\alpha}, \\
R_{t+1}^{L} E_{t} \beta_{t+1}^{E} u^{\prime}\left(d_{t+1}^{E}\right) / u^{\prime}\left(d_{t}^{E}\right)=1, \\
E_{t} \beta_{t+1}^{E}\left(u^{\prime}\left(d_{t+1}^{E}\right) / u^{\prime}\left(d_{t}^{E}\right)\right)\left\{\theta_{t+1} \alpha K_{t+1}^{\alpha-1} N_{t+1}^{1-\alpha}+q_{t+1}(1-\delta)\right\} / q_{t}=1, \text { with } q_{t} \equiv \xi^{\prime}\left(I_{t} / I\right) / \Xi_{t} .
\end{gathered}
$$

\section{The Home government}

At date $t$, the Home government makes exogenous random output purchases $G_{t}$ that are financed using lump sum taxes: $G_{t}=T_{t}^{W}+T_{t}^{E}+T_{t}^{B}$, where $T_{t}^{B}$ is a tax paid by the bank (see below). Each Home agent bears a constant share of the total Home tax burden, equal to her share in Home steady state consumption: $T_{t}^{i}=\lambda^{i} G_{t}^{i}$ for $i=W, E, B$ where $\lambda^{i}$ is timeinvariant. In setting taxes, the Home and Foreign governments assume that $50 \%$ of the banker's consumption takes place in country Home.

\section{The global bank}

The paper focuses on the role of bank capital for the transmission of macroeconomic and financial shocks to global real activity. The paper therefore adopts an aggregate 
perspective, and assumes a representative global bank that may be thought of as the global financial system. ${ }^{5}$ At $t$, the global bank receives deposits $D_{t+1}$ and $D_{t+1}^{*}$ from the Home and Foreign workers, respectively, and makes loans $L_{t+1}$ and $L_{t+1}^{*}$ to Home and Foreign entrepreneurs, respectively. Let $D_{t+1}^{W} \equiv D_{t+1}+D_{t+1}^{*}$ and $L_{t+1}^{W} \equiv L_{t+1}+L_{t+1}^{*}$ denote worldwide deposits and loans. The bank faces a capital requirement: her date $t$ capital $L_{t+1}^{W}-D_{t+1}^{W}$ should not be smaller than a fraction $\gamma_{t}$ of the bank's assets $L_{t+1}^{W}$. This may reflect a legal requirement (macro-prudential policy) or, more broadly, market pressures. To allow for time-variation in these factors, I assume that $\gamma_{t}$ is a random variable (exogenous to the bank). ${ }^{6}$ A sensitivity analysis below considers a model variant with a constant bank capital requirement $\left(\gamma_{t}=\gamma\right)$. Bank capital requirements are often justified as limiting moral hazard in the presence of informational frictions and deposit insurance (see Freixas and Rochet (2008)). This issue is not modeled here. Instead, I take the capital requirement as given, and focus on its macroeconomic effects. ${ }^{7}$

I assume that the bank can hold less capital than the required level, but this is costly. Let $x_{t} \equiv\left(L_{t+1}^{W}-D_{t+1}^{W}\right)-\gamma_{t} L_{t+1}^{W}=\left(1-\gamma_{t}\right) L_{t+1}^{W}-D_{t+1}^{W}$ denote the bank's 'excess' capital at the end of period $t$. The bank bears a cost $L^{W} \phi\left(x_{t} / L^{W}\right)$ as a function of $x_{t}$, where $L^{W}$ is the steady state stock of loans. $\phi$ is a convex function $\left(\phi^{\prime \prime} \geq 0\right)$ for which I assume:

\footnotetext{
5 Thus, the interbank market is not modeled here. Frictions in that market would matter for aggregate activity if they affected the total flow of funds from savers to borrowers. The model here captures empirical fluctuations in the loan spread and in the total volume of intermediation. To investigate the potential role of an interbank market, I studied a model variant with a savings bank and an investment bank. The savings bank gets deposits from households, and lends to the investment bank (interbank market), which lends to firms. Each bank faces a capital requirement and charges a loan spread. However, aggregate dynamics hinges on total bank capital--thus that set-up is observationally equivalent to the representative-bank model. ${ }^{6}$ The model could be used to evaluate the effects of alternative macro-prudential government policies that set $\gamma_{t}$ as a function of the state of the economy. However, policy comparisons, or the derivation of optimal macro-prudential policy rules, are beyond the scope of the paper. Mendicino and Punzi (2011) show that the introduction of macro-prudential tools may have important implications for real activity and welfare.

${ }^{7}$ See Meh and Moran (2010) for a closed economy DSGE model in which bank capital mitigates an agency problem between banks and their creditors. The authors assume that an exogenous fraction of bank earnings is kept for building bank capital, and that bank capital is held in the form of physical capital; credit crunches originate in shocks to the depreciation rate of bank-held physical capital. By contrast, in the model here, banks make loans (but do not hold physical capital), the fraction of retained bank earnings is endogenous (see below), and loan loss shocks are the main disturbance to bank capital.
} 
$\phi\left(x_{t} / L^{W}\right)>0$ for $x_{t}<0 ; \phi(0)=0$. Thus, for $x_{t}<0$ the bank incurs a positive cost; the cost is zero when the bank meets her capital requirement. ${ }^{8}$

At $t$, the bank also bears an operating cost $\Gamma \cdot\left(D_{t+1}^{W}+L_{t+1}^{W}\right)$, where $\Gamma>0$ is the (constant) real marginal cost of taking deposits and making loans. The bank's period $t$ budget constraint is:

$$
L_{t+1}^{W}+D_{t}^{W} R_{t}^{D}+\Gamma \cdot\left(D_{t+1}^{W}+L_{t+1}^{W}\right)+L^{W} \phi\left(x_{t} / L^{W}\right)+d_{t}^{B}+T_{t}^{B}+T_{t}^{B^{*}}=L_{t}^{W} R_{t}^{L}-\Delta_{t}-\Delta_{t}^{*}+D_{t+1}^{W},
$$

where $\Delta_{t}+\Delta_{t}^{*}$ is the bank's total loan loss, and $T_{t}^{B}+T_{t}^{B^{*}}$ is the total tax paid by the bank (in the two countries). $d_{t}^{B}$ is the dividend generated by the bank at $t$. (As the bank acts competitively, loan rates and deposit rates are equated across countries.) (7) implies that bank capital at the end of period $t$ equals bank capital at the end of $t-1$, plus retained bank earnings in $t$. The banker consumes her dividend income, and selects the path of loans and deposits to maximize her welfare. The banker's expected life-time utility at $t, V_{t}^{B}$, is:

$$
V_{t}^{B}=u\left(d_{t}^{B}\right)+E_{t} \beta_{t+1}^{B} V_{t+1}^{B} \text {, with } \beta_{t+1}^{B}=\beta^{B}\left(\overline{d_{t+1}^{B}}\right)<1 .
$$

The banker's utility maximization problem has these first-order conditions:

$$
\begin{gathered}
R_{t+1}^{D} E_{t} \beta_{t+1}^{B} u^{\prime}\left(d_{t+1}^{B}\right) / u^{\prime}\left(d_{t}^{B}\right)=1-\Gamma+\phi_{t}^{\prime}\left(x_{t} / L^{W}\right), \\
R_{t+1}^{L} E_{t} \beta_{t+1}^{B} u^{\prime}\left(d_{t+1}^{B}\right) / u^{\prime}\left(d_{t}^{B}\right)=1+\Gamma+\left(1-\gamma_{t}\right) \phi^{\prime}\left(x_{t} / L^{W}\right) .
\end{gathered}
$$

A linear approximation of these Euler equations (around $x=0$ ) gives:

$$
R_{t+1}^{L}-R_{t+1}^{D} \cong 2 \Gamma-\gamma_{t} \phi^{\prime}\left(x_{t} / L^{W}\right) \cong 2 \Gamma-\gamma_{t} \phi^{\prime}(0)-\gamma \phi^{\prime \prime}(0) \cdot\left(x_{t} / L^{W}\right) .
$$

Hence, the loan rate spread $R_{t+1}^{L}-R_{t+1}^{D}$ is a function of the required capital ratio $\gamma_{t}$ and of the bank's excess capital, $x_{t}$. Note that if the bank raises deposits and loans by one unit, then her operating cost rises by $2 \Gamma$ units; excess bank capital falls by $\gamma_{t}$, which raises the

\footnotetext{
${ }^{8}$ Gerali et al. (2010) assume a quadratic cost function $\phi\left(x_{t}\right)=\frac{1}{2} \chi \cdot\left(x_{t}\right)^{2}, \chi>0$, under which the bank also bears a cost when $x_{t}>0$. This function satisfies my assumptions. My setup is more general, as it allows for the possibility that positive excess capital generates a convenience yield $\left(\phi\left(x_{t}\right)<0\right.$ for $\left.x_{t}>0\right)$. Up to a linear approximation (around $x=0$ ), both specifications yield identical predictions; in particular, the loan rate spread is decreasing in $x_{t}$ if and only if $\phi^{\prime \prime}(0)>0$ (see below); the key assumption is, hence, the convexity of $\phi$, which seems uncontroversial.
} 
penalty $L^{W} \phi\left(x_{t} / L^{W}\right)$ by $-\gamma_{t} \phi^{\prime}\left(x_{t} / L^{W}\right)$. The bank's Euler equations imply that the spread between the loan rate and the deposit rate $R_{t+1}^{L}-R_{t+1}^{D}$ covers the marginal cost $2 \Gamma-\gamma_{t} \phi^{\prime}\left(x_{t} / L^{W}\right)$. Under strict convexity of $\phi$ (i.e. $\phi^{\prime \prime}>0$ ), the marginal benefit of excess capital $-\phi^{\prime}$ is a decreasing function of (excess) bank capital, which implies that the loan rate spread is likewise a decreasing function of excess bank capital.

The sensitivity of the loan rate spread to changes in bank capital is governed by $\phi^{\prime \prime}$. Note that $x_{t} / L^{W} \cong c r_{t}-\gamma_{t}$, where $c r_{t} \equiv\left(L_{t+1}^{W}-D_{t+1}^{W}\right) / L_{t+1}^{W}$ is the bank's capital ratio, i.e. the ratio of bank equity to bank assets. A one percentage point rise in the capital ratio lowers the loan rate spread by $4 \gamma \phi^{\prime \prime}$ percentage points per annum (p.a.), while a one percentage point increase in the required bank capital ratio (holding constant $C r_{t}$ ) raises the spread by $4\left[\gamma \phi^{\prime \prime}-\phi^{\prime}\right]$ percentage points p.a..

\section{Market clearing}

Market clearing for the output good requires:

$Z_{t}+Z_{t}^{*}=C_{t}^{S}+C_{t}^{S^{*}}+d_{t}^{E}+d_{t}^{E^{*}}+d_{t}^{B}+I \xi\left(I_{t} / I\right)+I^{*} \xi\left(I_{t}^{*} / I^{*}\right)+G_{t}+G_{t}^{*}+L^{W} \phi\left(x_{t} / L^{W}\right)+\Gamma \cdot\left(L_{t+1}^{W}+D_{t+1}^{W}\right)$.

\section{Forcing variables}

Steady state TFP and investment efficiency are normalized to unity $\left(\theta=\theta^{*}=\Xi=\Xi^{*}=1\right)$. There are 11 forcing variables: Home and Foreign TFP $\left(\theta_{t}, \theta_{t}^{*}\right)$, investment efficiency $\left(\Xi_{t}, \Xi_{t}^{*}\right)$, government purchases $\left(G_{t}, G_{t}^{*}\right)$, labor supply shocks $\left(\Psi_{t}^{N}, \Psi_{t}^{N^{*}}\right)$, loan losses $\left(\Delta_{t}, \Delta_{t}^{*}\right)$ and the required bank capital ratio $\left(\gamma_{t}\right)$. I refer to the first 8 shocks as 'nonbanking' shocks, and to the last three shocks as 'banking shocks'. A large number of nonbanking shocks is assumed so that the model has the potential to capture important features of macro data, even in the absence of banking shocks. Other recent estimated DSGE models likewise assume many shocks (e.g., Smets and Wouters (2007)).

I consider two specifications of the law of motion of the forcing variables-empirical results regarding the transmission of banking shocks to real activity are broadly 
similar across the two specifications. The first specification follows the empirical DSGE literature and assumes that all 11 forcing variables are univariate AR(1) processes:

$$
\ln \left(z_{t} / z\right)=\rho^{z} \ln \left(z_{t-1} / z\right)+\varepsilon_{t}^{z},
$$

for variable $z_{t}$, with $0 \leq \rho^{z}<1$, where $\varepsilon_{t}^{z}$ is a normally distributed white noise. The AR(1) parameters are estimated jointly with the behavioral parameters. Independence of shocks makes it easy to decompose the variance of endogenous variables into components associated with each shock. However, that specification does not capture the correlations between empirical measures of the forcing variables (see below).

I thus also consider a second specification with correlated shocks. Specifically, the second specification assumes that the 8 'non-banking' shocks follow univariate AR(1) processes with correlated innovations, while the laws of motion of loan losses and of the required bank capital ratio are of this form:

$$
\begin{gathered}
\Delta_{t} / Y=\rho^{\Delta} \Delta_{t-1} / Y+\vartheta^{\Delta} \ln \left(Y_{t} / Y\right)+\varepsilon_{t}^{\Delta}, \Delta_{t}^{*} / Y^{*}=\rho^{\Delta^{*}} \Delta_{t-1}^{*} / Y^{*}+\vartheta^{\Delta} \ln \left(Y_{t}^{*} / Y^{*}\right)+\varepsilon_{t}^{\Delta^{*}}, \\
\gamma_{t}=\left(1-\rho^{\gamma}\right) \gamma+\rho^{\gamma} \gamma_{t-1}+\vartheta^{\gamma} \ln \left(Y_{t}^{W} / Y^{W}\right)+\varepsilon_{t}^{\gamma},
\end{gathered}
$$

with $0 \leq \rho^{\Delta}, \rho^{\Delta^{*}}, \rho^{\gamma}<1 . Y_{t}, Y_{t}^{*}$ and $Y_{t}^{W} \equiv Y_{t}+Y_{t}^{*}$ are Home and Foreign GDP and world GDP respectively. ${ }^{9} \varepsilon_{t}^{\Delta}, \varepsilon_{t}^{\Delta *}$ and $\varepsilon_{t}^{\gamma}$ are independent normal white noises. The vector of innovations $\varepsilon_{t}^{b k} \equiv\left(\varepsilon_{t}^{\Delta}, \varepsilon_{t}^{\Delta^{*}}, \varepsilon_{t}^{\gamma}\right)$ is assumed independent of the vector of innovations to the 8 'non-banking' forcing variables, denoted by $\varepsilon_{t}^{n b k}$, at all leads and lags. To allow for correlation between the banking shocks, and between those shocks and the non-banking forcing variables, equations (10),(11) assume that $\left(\Delta_{t}, \Delta_{t}^{*}, \gamma_{t}\right)$ depends on GDP and thus is partly endogenous. The independence of $\varepsilon_{t}^{n b k}$ and $\varepsilon_{t}^{b k}$ makes it straightforward to decompose the variance of the endogenous variables into components due to $\varepsilon_{t}^{n b k}$ and

\footnotetext{
${ }^{9}$ The bank's operating costs and the costs of excess bank capital $L^{W} \phi\left(x_{t} / L^{W}\right)$ represent inputs used by the bank; these costs thus have to be subtracted from the entrepreneurs' output when computing GDP. I assume that the resources used by Home banking $\Gamma \cdot\left(L_{t+1}+D_{t+1}\right)$ are purchased from the Home entrepreneur, and that a fraction $L / L^{W}$ of the resource cost $L^{W} \phi\left(x_{t} / L^{W}\right)$ is likewise purchased from the Home entrepreneur. Hence, Home GDP is: $Y_{t} \equiv Z_{t}-\Gamma\left(L_{t+1}+D_{t+1}\right)-L \phi\left(x_{t} / L^{W}\right)$.
} 
$\varepsilon_{t}^{b k}$, respectively. (The covariance matrix of non-banking shocks is calibrated, while the parameters of (10),(11) are estimated; see below.)

\subsection{Model solution}

A linear approximation (around the deterministic steady state) is used to solve the model. The solution can be expressed as

$$
S_{t}=\Lambda_{1} S_{t-1}+\Lambda_{2} \varepsilon_{t},
$$

where $s_{t}$ is a vector consisting of states and controls chosen (or realized) in period $t$,

expressed as deviations from steady state values. $\varepsilon_{t} \equiv\left(\varepsilon_{t}^{n b k}, \varepsilon_{t}^{b k}\right)$ is the vector of date $t$ innovations to the forcing variables. $\Lambda_{1}$ and $\Lambda_{2}$ are matrices whose elements are functions of the model parameters.

\section{Econometric approach}

The model is estimated using quarterly time series for 12 macro and banking variables, in 1990q1-2010q3: US and EA GDP, total private consumption, investment, employment, commercial bank credit (deflated using the GDP deflator), the loan rate spread of US commercial banks, and the capital ratio of US commercial banks. US (EA) data are taken as empirical counterparts of Home (Foreign) variables in the model. The baseline estimates use data on total bank credit (to all sectors) by US Commercial banks and by EA Monetary financial institutions (MFI). Below, I also report estimation results that use data on credit to the business sector. (I use total credit for the baseline estimates, as that variable accounts for a greater share of bank assets.) The baseline measure of the US loan rate spread is the series 'commercial and industrial loan rates spread over intended federal funds rate', from the Federal Reserve Board's (FRB) Survey of Terms of Business Lending (Table E.2). Data on the EA loan rate spread are only available for the period since 2003q1; as shown in Figure 2, the available EA loan spread closely tracks the US loan spread (correlation in 2003-2010: 0.90). (The EA spread plotted in Fig. 2 is the difference between the EA MFI loan rate and the EONIA rate.) I thus use the US loan rate spread as a measure of the global loan rate spread. The US Commercial bank capital ratio is taken as a proxy for the capital ratio of the global bank. The empirical bank 
capital ratio measure is constructed as (total financial assets - total liabilities)/total financial assets, using data from the Flow of Funds (FRB). See the Appendix for further information on the empirical variables. In estimation, the loan spread and the capital ratio are demeaned, while the other empirical variables are linearly detrended in log-form.

The number of data series used for estimation (12) exceeds the number of shocks (11). To avoid stochastic singularity of the model, I assume that observed variables contain measurement error. Allowing for measurement error also seems important because (especially) the empirical banking series might be imperfect measures of the theoretical concepts. ${ }^{10}$ The period $t$ data used in estimation, $y_{t}^{o b s}$, are a subset of the states and controls included in the vector $s_{t}$ (see (12)), and are measured with error:

$$
y_{t}^{o b s}=\Gamma s_{t}+\mu_{t}
$$

where $\Gamma$ is a matrix, and $\mu_{t}$ is a vector of Gaussian i.i.d. measurement errors that are independent of the true state variables at all leads and lags. I use a Bayesian approach to estimate a subset of the parameters, while the remaining parameters are calibrated.

\subsection{Preference, technology and banking parameters}

I estimate the (scaled) curvature of the bank capital penalty function $4 \gamma \phi$ ", the curvature of the investment cost function $\xi "$ and the risk aversion coefficient, $\sigma$. The first two parameters do not affect the steady state, but are key for the dynamic properties of the model. In particular, $4 \gamma \phi^{\prime \prime}$ (sensitivity of the loan rate spread to changes in the bank capital ratio) is crucial for the transmission of banking shocks to real activity.

The means and standard deviations of the prior distributions of these parameters are shown in Cols. (1)-(2) of Table 2. I set the mean of the prior distribution of $4 \gamma \phi^{\prime \prime}$ at 0.2 , a value consistent with time series regressions of the loan rate spread on aggregate bank capital reported by Kollmann et al. (2011). (As discussed below, I set the steady state required bank capital ratio at $\gamma=11.17 \%$.) Investment is excessively volatile when

\footnotetext{
${ }^{10}$ To break the singularity, measurement error in just one observable is sufficient. To determine the presence of measurement error empirically, I allow for it in all series. Assuming measurement error just in banking variables gives the same results about the role of banking shocks. For recent empirical DSGE models that explicitly allow for measurement error see Ireland (2004), Boivin and Giannoni (2006), Gali et al. (2011) and de Antonio (2011). Sizable estimated measurement error may suggest model misspecification (Canova (2007)).
} 
the capital accumulation technology is linear $(\xi "=0)$, as then international capital flows respond very strongly to country-specific shocks. I set the mean of the prior distribution of $\xi "$ at 1 ; for that value, the ratio of the standard deviation of investment divided by the standard deviation of GDP is about 3 in the model variants discussed below, and thus roughly in the range of the relative volatility of EA investment, when the other parameters are set at prior mean values. The mean of the prior distribution of $\sigma$ is set at unity. (The prior distributions of $\sigma, 4 \gamma \phi^{\prime \prime}$ and $\xi "$ are Gamma distributions with standard deviations set at half the prior means. Thus a reasonably wide range of parameter values around the mean has non-negligible mass.)

\section{Calibrated parameters}

I calibrate the remaining structural parameters so that the steady state matches long run properties of the data. It would be difficult to estimate the calibrated parameters through the lens of the model, using the (detrended) empirical time series used for estimation (see Smets and Wouters (2007)). One period in the model represents one quarter in calendar time. As is standard in the macro literature, the (quarterly) depreciation rate of physical capital is set at $\delta=0.025$. The elasticity of output with respect to capital is set at $\alpha=0.3$, consistent with long run average historical US and EA labor shares of about 70\%.

The two-country model here abstracts from US and EA trade with third countries; I thus use the sum of US government consumption and of US net exports to countries other than the EA as an empirical measure of US 'autonomous' spending, $G_{t}$; EA autonomous spending is constructed analogously. During 1990q1-2010q3, US [EA] autonomous spending represented $14.2 \%$ of US GDP [21.2\% of EA GDP], on average. I take the US as the empirical counterpart of country 'Home' and set $G / Y=14.2 \%$, $G^{*} / Y^{*}=21.2 \%$

Most DSGE studies calibrate the subjective discount factor to match average historical returns. I use the same approach. As mentioned above, it is assumed that all agents have the same steady state subjective discount factor, here denoted by $\beta$. $\beta$ is set so that the steady state loan rate matches the mean 1990q1-2010q3 US real loan rate. I use the interest rate on 'commercial and industrial loans made by all commercial banks' 
reported by the FRB (Survey of Terms of Business Lending, Table E.2) as a measure of the nominal loan rate, from which I subtract the quarterly growth rate of the US GDP deflator to construct the real loan rate. The average US real loan rate 1990q1-2010q3 was $3.440 \%$ p.a.. Accordingly, I set the (quarterly) steady state subjective discount factor at $\beta=0.9918$ (as $\beta R^{L}=1$, from the entrepreneur's Euler equation (6)).

I assume that all agents' subjective discount factors have the same elasticity with respect to consumption, denoted by $\varepsilon_{\beta}$. I set $\varepsilon_{\beta}$ at a small absolute value, $\varepsilon_{\beta}=-0.001$, that yields a stationary equilibrium, while generating (essentially) the same short run dynamics as a model variant with a constant subjective discount factor. (Impulse responses over the first 100 periods are very similar across model variants with $\varepsilon_{\beta}=0$ and $\varepsilon_{\beta}=-0.001$.)

The sample mean (1990q1-2010q3) of the US loan rate spread was $2.161 \%$ p.a.. ${ }^{11}$ I set the steady state deposit rates in the model at $1.279 \%$ p.a., so that the steady state loan rate spread matches the mean historical spread, 2.161\%. The mean EA loan spread was $2.01 \%$ in $2003-2010$ (see above), which is close to the steady state spread assumed in the model calibration.

I set the steady state actual and required bank capital ratios at $c r=\gamma=11.17 \%$, which corresponds to the average capital ratio of US commercial banks during the sample period (from Flow of Funds data). The bank's Euler equations imply $R^{D} \beta=1-\Gamma+\phi^{\prime}$ and $R^{L} \beta=1+\Gamma+(1-\gamma) \phi^{\prime}$. Given the steady state deposit and loan rates, these two conditions pin down the bank's marginal operating cost $\Gamma$ and the steady state slope of the bank's 'penalty' function $\phi^{\prime}$ : $\Gamma=0.25 \%, \phi^{\prime}=-0.28 \% . c r=\gamma$ implies that steady state excess bank capital is zero, $x=0$, i.e. $L^{W}(1-\gamma)=D^{W} .{ }^{12}$ I set $L(1-\gamma)=D$ and $L^{*}(1-\gamma)=D^{*}$, i.e. the steady state ratio of deposits to loans is the same in both countries (as is consistent with the data). The ratio of outstanding US commercial bank loans to annual US GDP was

\footnotetext{
${ }^{11}$ As mentioned above, the baseline measure of the US loan rate spread is the 'commercial and industrial loan rates spread over intended federal funds rate'. Using the rate on short term Certificates of Deposit as a measure of the bank's marginal funding costs yields a loan rate spread that has a 0.75 correlation with the baseline spread, and a sample mean of $1.929 \%$ p.a., which is close to the assumed steady state spread.

${ }^{12}$ Setting steady state excess capital at a non-zero value generates the same behavior, provided the calibration matches the same steady state deposit and loan rates (as in the baseline calibration with $x=0$ ).
} 
53\% on average in 1990q1-2010q3, while the mean ratio of the stock of EA MFI loans divided by annual EA GDP was $87 \%$. Thus, the US has a noticeably lower loans/GDP ratio than the EA. The calibration reflects this: I assume that the steady state ratios of loans to annual GDP are 53\% in country 'Home', and 87\% in 'Foreign'. Finally, I assume that both countries have the same steady state GDP, normalized at unity: $Y=Y^{*}=1$. These steady state targets pin down the remaining preference parameters (the weights of deposits in Home and Foreign workers' utility functions, $\Psi^{D}, \Psi^{D^{*}}$, and steady state marginal disutilities of labor, $\left.\Psi^{N}, \Psi^{N *}\right) .^{13}$

\subsection{Processes of forcing variable, measurement error}

The first specification of the law of motion of the forcing variables assumes that those variables follow independent $\mathrm{AR}(1)$ processes; I estimate the autocorrelations of the 11 forcing variables, and the standard deviations of the 11 shock innovations, through the lens of the model, using the Bayesian approach. ${ }^{14}$

The second specification assumes correlated forcing variables. The parameters of the laws of motion (10)-(11) of loan losses and of the required bank capital ratio are estimated via the model (using the Bayesian approach). ${ }^{15}$ By contrast, I calibrate the process governing non-banking shocks, as empirical measures of the non-banking shocks can easily be constructed, and as estimation of the correlation matrix of these shocks through the lens of the model would be challenging (given the large number of crosscorrelations). Specifically, I set the autocorrelations of the 8 non-banking forcing variables, and the covariance matrix of these variables, equal to the sample autocorrelations and sample covariance matrix of empirical measures of the non-banking shocks (1990q1-2010q3), respectively (see Table 1). Following Coeurdacier, Kollmann

${ }^{13}$ (3) implies $\Psi^{D}=\left(1-R^{D} \beta\right)\left(\left(C^{S} / Y\right) /(D / Y)\right)^{-\sigma}$. D/Y is determined by $L / Y$, while $C^{S} / Y$ is pinned down by ratios of government purchases and investment to GDP. $Y=1$ then pins down $\Psi^{N}$ (as $\Psi^{N}$ determines the steady state labor input). In steady state, consumption by the Home [Foreign] worker and the entrepreneur represent respectively $58.2 \%$ and $4.8 \%$ [52.3\% and 3.5\%] of domestic GDP, while the banker's consumption represents $0.21 \%$ of world GDP.

${ }^{14}$ The prior distributions of the autocorrelations [standard deviations of shock innovations] have mean 0.5 [0.5\%] and a standard deviation equal to 0.1 . Using more diffuse priors leaves the results unchanged.

${ }^{15}$ The prior mean of the standard deviations of $\varepsilon_{t}^{\Delta}, \varepsilon_{t}^{\Delta *}$ and $\varepsilon_{t}^{\gamma}$ is set at $0.5 \%$; the prior mean of the autoregressive coefficients $\rho^{\Delta}, \rho^{\Delta^{*}}, \rho^{\gamma}$ is 0.5 ; the prior mean of the coefficients of GDP, $\vartheta^{\Delta}$ and $\vartheta^{\gamma}$, is 0 . 
and Martin (2010), I use the ratio of the CPI to the investment deflator as a measure of investment efficiency. The empirical labor supply shock is constructed as $\Psi_{t}^{N}=(1-\alpha)\left(Z_{t} / N_{t}\right) / C_{t}$, which follows from the first order conditions (2),(5) when $\sigma=1$ (i.e. when $\sigma$ equals its prior mean). Thus, the empirical labor supply shock is proportional to labor productivity divided by consumption. ${ }^{16}$ As reported in Table 1, US investment efficiency, US autonomous spending and the US labor supply shock are more volatile than the corresponding EA variables. The cross-country correlations of TFP (0.51) and investment efficiency (0.84) are sizable. TFP is positively correlated with investment efficiency; US and EA TFP are strongly negatively correlated with US autonomous spending $(G)$, and negatively correlated with the US labor supply shock. All forcing variables are highly persistent (autocorrelations in the range 0.80-0.98).

The prior means and prior standard deviations of the standard deviations of measurement errors are set at $1 / 4$ and $1 / 20$, respectively, of the standard deviations of the corresponding (demeaned/detrended) empirical series.

\section{Data plots and business cycle statistics.}

Figure 1 plots the (demeaned/detrended) 12 empirical quarterly time series (1990q12010q3) used in estimation. Macro aggregates co-move closely across the US and the EA - the synchronicity was especially high during the 'Great Recession' of 2007q42009q2 (as dated by the NBER). (Shaded areas in Figures indicate NBER recessions.) Relative to trend, US output fell by $8.5 \%$, during the recession, while EA output fell by 7.5\%; US consumption (-7.3\%) and investment (-35.1\%) fell more sharply than EA consumption (-4.0\%) and investment (-15.9\%). US and EA bank lending grew strongly in the years before 2008, and then decreased sharply. The loan rate spread fell during the three years prior to the crisis, but rose sharply during the Great Recession. The bank capital ratio exhibits relatively mild fluctuations--throughout the sample period it stays in a $\pm 2 \%$ range around the sample mean of $11.17 \%$.

\footnotetext{
${ }^{16}$ Labor productivity is constructed using GDP as a proxy for the entrepreneur's output $Z$. I also considered an alternative measure of the labor supply shock based on real wage rate data: $\Psi_{t}^{N}=\omega_{t} / C_{t}$. That measure gives similar estimates of model parameters and of the role of banking shocks.
} 
Figure 3 plot the bank capital ratio, together with the baseline loan spread series and two other spread measures that are used for robustness checks below (all series in Figure 3 are demeaned). Except for the period of the financial crisis, the bank capital ratio and the baseline loan rate spread comove negatively. While the baseline loan rate spread rose, during the crisis (as mentioned above), the bank capital ratio has had a flat trend since about 2005 -- it has been argued that this may partly reflect accounting discretion, which has allowed banks to overstate the value of their assets in the crisis (Huizinga and Laeven (2009)). The correlation between the bank capital ratio and the baseline lending spread was -0.46 during the period $1990-2007$, and -0.06 over the whole sample period.

Figure 3 also plots the US series 'net percentage of banks increasing spreads of loan rates over cost of funds', from the FRB Senior Loan Officer Opinion Survey on Bank Lending Practices, SLOOS. (The series represents the percentage of banks increasing spreads minus the percentage of banks lowering spreads; the plotted series is scaled so that its standard deviation equals that of the baseline loan spread.) That series is positively correlated with the baseline loan spread (correlation 0.39 for 1990-2010), and negatively correlated with the bank capital ratio (-0.47 for 1990-2007; -0.21 for 19902010). Also plotted in Figure 3 (see right panel) is Gilchrist and Zakrajšek’s (2011a) excess US commercial bond premium, constructed by subtracting expected bond default probabilities from the spread between the yield on US commercial bonds and the yield on US Treasury bonds. As commercial banks are key players in the commercial bond market, the commercial bond premium might be informative about credit spreads/market conditions. (Gilchrist and Zakrajšek (2011a) argue that 'an increase in the excess bond premium reflects [...] a contraction of the supply of credit with significant adverse consequences for the macroeconomy', p.31.) The excess bond premium too is negatively correlated with the bank capital ratio (correlation: -0.49 for 1990-2007; -0.15 for 19902010). The bond premium is positively correlated with the baseline loan rate spread (0.29) and with the SLOOS 'net percentage of banks increasing spreads' (0.79).

Overall, the data are thus consistent with the model's key prediction that the spread is inversely related to the bank capital ratio (see (8)). The absence of a pronounced inverse relation during the crisis might be due to the fact that the measured bank capital ratio overstates the true capital ratio during the crisis (see discussion above), or that the 
required bank capital ratio rose during the crisis (this could rationalize the observed increase in the loan rate spread, during the crisis, without a fall in the bank capital ratio).

The last Column of Table 3 reports moments of Hodrick-Prescott (HP) filtered quarterly macro and banking variables, for the US and the EA (1990q1-2010q3). (The smoothing parameter is set at 1600.) The standard deviation of GDP is very similar in the US (1.12\%) and the EA (1.14\%). Consumption is less volatile than GDP, while investment is markedly more volatile than GDP. US investment is almost twice as volatile as EA investment. In both 'countries', loans are more volatile than output, and the loan spread is countercyclical. Real activity and loans are positively correlated across the US and EA.

\section{Estimation results}

\subsection{Posterior parameter estimates (Table 2)}

Columns (4)-(5) of Table 2 report the mean and the standard deviation of the posterior parameter distribution, for the model variant with independent shocks. ${ }^{17}$ Cols. (8)-(9) report posterior parameter estimates for the model variant with correlated shocks.

The data are informative about the estimated parameters: in almost all cases, the posterior parameter distributions have lower standard deviations than the prior distributions; the posterior means often differ noticeably from the prior means (posterior means and modes are very close). With independent shocks, the posterior mean of $4 \gamma \phi^{\prime \prime}$ indicates that a 1 percentage point increase in the bank capital ratio leads to a 21 basis point reduction in the annualized loan rate spread, and that a 1 percentage point rise in the required bank capital ratio $\left(\gamma_{t}\right)$ increases the loan rate spread by 19 basis points p.a.. ${ }^{18}$ In the model variant with correlated shocks, the posterior estimates suggest that the spread is about twice as sensitive to changes in the bank capital ratio: $4 \gamma \phi^{\prime \prime}=0.48$.

\footnotetext{
${ }^{17}$ The means and standard deviations of the posterior distributions were generated using the Random Walk Metropolis algorithm (see An and Schorfheide (2007)).

18 The posterior means of the spread sensitivity $4 \gamma \phi^{\prime \prime}$ and risk aversion $\sigma$ are close to prior means. I experimented with larger prior means of these parameter, and found that the posterior means remain close to the posterior means reported in Table 2, which indicates that the data are informative about these parameters.
} 
The posterior estimates of the model with independent shocks indicate that EA loan loss shocks are roughly as volatile as US loan loss shocks-the posterior modes of the standard deviations of $\varepsilon_{t}^{\Delta}$ and $\varepsilon_{t}^{\Delta *}$ are $0.71 \%$ and $0.79 \%$, respectively, in the model variant with independent shocks, while the model with correlated shocks implies that EA loan losses are more volatile than US loan losses. The required bank capital ratio undergoes sizable fluctuations (posterior mode of std. of $\varepsilon^{\gamma}: 0.5 \%-0.6 \%$ ). The posterior means of the standard deviations of measurement errors are mostly smaller than the prior means (an exception is the measurement error for the bank capital ratio).

\subsection{Business cycle moments implied by posterior parameter estimates (Table 3)}

Cols. (1)-(9) of Table 3 report model-predicted moments of HP filtered US and EA variables (computed at the posterior mode of the estimated parameters), for the model variant with independent shocks. Column (1) [labeled 'All'] assumes all 11 structural shocks, and measurement error. Cols. (2)-(9) consider moments generated by different subsets of the structural shocks, in isolation, without measurement error. Specifically, Col. (2) ['NonBk'] assumes just the 8 non-banking shocks $\varepsilon_{t}^{n b k}$, and Col. (3) ['Bnk'] assumes just the 3 exogenous banking shocks $\varepsilon_{t}^{b k}$. Cols. (4)-(9) assume just a single type of shock (Col.(4): just TFP shocks; Col. (5): just investment efficiency shocks; etc.). ${ }^{19}$

The independent-shocks model with all shocks and measurement error generates predicted standard deviations that are mostly in the range of the empirical statistics. The predicted standard deviations of US GDP (1.14\%) and of EA GDP (1.22\%) are close to the empirical standard deviations (1.12\%, 1.14\%); see Columns (1) and (15). The model (with all shocks) captures the fact that investment is more volatile than GDP. The model also captures the high volatility of US loans, but it underpredicts the volatility of EA loans. It matches the procyclical behavior of the macro aggregates, employment and loans, and correctly predicts that the loan spread is countercyclical. However, the model

\footnotetext{
${ }^{19}$ Using (12),(13), the model solution for observables (with measurement error) can be written as: $y_{t}^{\text {obs }}=$ $A(L) \varepsilon_{t}^{n b k}+B(L) \varepsilon_{t}^{b k}+\mu_{t}$ where $A(L)$ and $B(L)$ are lag polynomials. (The moments in Table 3 pertain to HP filtered series, $y_{t}^{o b s, H P}=H(L) y_{t}^{o b s}$, where $H(L)$ is the HP filter.) By assumption, $\varepsilon_{t}^{n b k}, \varepsilon_{t}^{b k}$ and $\mu_{t}$ are independent at all leads and lags. Thus the predicted variance of endogenous variables under all shocks and measurement error is the sum of: (i) the variance with just non-banking shocks; (ii) the variance with just banking shocks; (ii) the variance of measurement error.
} 
with all (independent) shocks predicts cross-country correlations of GDP (-0.26), investment (-0.02) and employment (-0.24) that are negative, and thus markedly below the empirical (positive) correlations. But note that the predicted cross-country consumption correlation (0.24) is positive, and thus much closer to the empirical correlation (0.39). ${ }^{20}$

Taken in isolation, TFP shocks and labor supply shocks induce by far the largest fluctuations in real activity (predicted standard deviations of US GDP with just these shocks: $0.78 \%$ and $0.62 \%$, respectively). The predicted standard deviations of US GDP with just loan loss shocks $(0.18 \%)$ and with just shocks to the required bank capital ratio $(0.08 \%)$ are noticeably lower. With just (uncorrelated) TFP shocks, and just labor supply shocks, GDP is negatively correlated across countries. This is due to the fact that these shocks are negatively transmitted internationally-e.g. a positive shock to Home TFP raises Home GDP, but lowers Foreign GDP (see below). By contrast, government purchases shocks and the banking shocks induce strong positive cross-country output correlations. Notice that the banking shocks induce a strong negative correlation between the loan rate spread and GDP.

Predicted moments generated by the model variant with correlated shocks are reported in Cols. (12)-(14) of Table 3. The predicted standard deviations and crosscorrelations with domestic GDP are mostly in the same range as the corresponding moments generated by the structure with independent shocks. ${ }^{21}$ However, the variant with correlated shocks generates sizable positive cross-country correlations of output (0.45) and investment $(0.31)$ that are close to the empirical correlations; the predicted cross-country consumption correlation (0.75) exceeds the empirical correlation. Standard

\footnotetext{
${ }^{20}$ In open-economy DSGE models, the predicted cross-country consumption correlation exceeds the crosscountry output correlation, provided internationally traded assets allow the residents of different countries to (partially) share their consumption risk (Kollmann $(1996,2012)$ ). Consumption would be perfectly correlated across the two countries, if complete financial markets existed.

${ }^{21}$ In independent-shocks model, loan losses and the required capital ratio are negatively correlated with GDP (as a rise in losses and in the required capital ratio lowers output; see below). In the correlated-shocks model variant, the posterior estimates of the response coefficients of loan losses and the required bank capital ratio to GDP $\left(\vartheta^{\Delta}, \vartheta^{\gamma}\right)$ are both positive but close to zero (0.07); see (10)-(11). This implies that the required bank capital ratio is positively correlated with loan losses. The implied correlations of US GDP with the US loan loss and the world loan loss are 0.18 and -0.04 , respectively; EA GDP is predicted to be negatively correlated with the EA loan loss $(-0.17)$ and the world loan loss $(-0.16)$. Imposing a zero response coefficients of the US loan loss to GDP yields a negative correlation between the US loan loss and US GDP, but it barely affects estimates of remaining parameters and other predicted moments.
} 
International RBC models without banks (e.g., Backus, et al. (1992), Baxter and Crucini (1995), Kollmann (1996)) too generate cross-country correlations of real activity that are lower than the empirical cross-country correlations, unless shocks are highly correlated across countries, and the same also holds for variants of the present model without an operative bank capital requirement $\left(\phi^{\prime \prime}=0\right)$; see below.

\subsection{Variance shares accounted for by banking shocks (Table 4)}

Table 4 reports the \% shares of the predicted variances of HP filtered endogenous variables (with measurement error) that are accounted for by the non-banking shocks $\varepsilon_{t}^{n b k}$ (see rows labeled 'NonBk'), and by the banking shocks $\varepsilon_{t}^{b k}$ (rows labeled 'Bank'); the remainder represents the contribution of measurement error to the predicted variance. (The variance shares are computed at the posterior mode of the estimated parameters.)

According to the model variant with independent shocks, the banking shocks account for a 3.1\% share of US GDP variance, but explain larger shares of the variances of US investment (6.1\% share), employment (6.3\%) and loans (41.0\%); see Panel (a1) of Table 4. Banking shocks account for greater variance shares of EA variables--GDP: 4.0\%; investment: 22.6\%; employment: $7.8 \%$; loans: $72.0 \%$. Thus, roughly one-fifth of the variance of EA investment is due to banking shocks, according to the model with independent shocks. Banking shocks account for 59.7\% of the variance of the bank capital ratio, and for $84.7 \%$ of the variance of the loan rate spread. ${ }^{22}$

The estimation results also show that loan loss shocks are more important drivers of real activity than shocks to the required bank capital ratio; the latter explain merely $0.5 \%$ of the variances of US and EA GDP, in the model variant with independent shocks (see rows labeled ' $\Delta^{U S} ',{ }^{E A}{ }^{E A}$ and ' $\Delta^{\gamma}$ ' in Panel (a1) of Table 4).

In the model variant with correlated shocks, the variance shares of real activity induced by the three joint banking shocks are 1.7-3.5 times greater than in the estimated model with independent shocks; see Panel (b) of Table 4. Banking shocks now account for $5.5 \%$ (14.2\%) of the variance of US (EA) GDP, and for $10.6 \%$ (53\%) of the variance

\footnotetext{
${ }^{22}$ Non-banking shocks explain only a negligible share of the variance of the bank capital ratio and the loan rate spread. A sizable share of the variance of the bank capital ratio (40.1\%) is thus accounted for by measurement error.
} 
of US (EA) investment. Intuitively, when the processes of the non-banking shocks are calibrated, then the estimated banking shock processes bear a greater burden of fitting the data (and thus account for greater variance shares).

These findings suggest that banking shocks account for a non-negligible share of the variance of real activity. Specifically, banking shocks account for $3 \%-5 \%$ of the unconditional variance of US GDP, and for $4 \%-14 \%$ of the variance of EA GDP. The variance shares of investment accounted for by banking shocks are higher, especially for the EA (above 20\%). ${ }^{23}$ EA real activity thus depends more on banking shocks than US real activity. Interestingly, US loan losses account for a greater share of the variance of EA real activity than of the variance of US real activity. This finding is in line with Helbling et al. (2011) who argue, based on vector autoregressions, that US credit supply shocks account for a greater share of fluctuations in global GDP than of US GDP.

A robustness analysis below confirms the findings discussed in this Section. ${ }^{24}$

\subsection{Impulse responses (Table 5)}

Impulse responses (reported in Table 5) help to understand the model's mechanics, and the predicted business cycle moments. The impulse responses are computed at the posterior mode of estimated model parameters, for the baseline model with independent shocks. Each impulse response focuses on an isolated innovation, assuming that all other exogenous innovations are zero. (To save space, Table 5 does not show responses to EA 'non-banking' shocks - those responses are qualitatively similar to the responses to US 'non-banking' shocks.)

A positive innovation to Home TFP raises Home GDP and investment, but leads to a fall in Foreign GDP. The shock raises the income of the Home worker; thus that worker saves more, and her holdings of bank deposits increase--i.e. the bank's debt rises, which lowers the bank capital ratio. The deposit rate falls (due to the greater supply of

\footnotetext{
${ }^{23}$ The estimates here suggest a more important role for banking shocks than illustrative calibrations in Kollmann et al. (2011), according to which banking shocks account for less than $0.2 \%$ of the variance of real activity. This greater role is due to the fact that the estimated sensitivity of the loan spread to bank capital here, and the estimated variance of loan losses, are larger than corresponding parameters assumed in those calibrations.

${ }^{24}$ Nolan and Thoenissen (2009) and Jermann and Quadrini (2012) use closed economy models with collateral-constrained firms (but without banks) to construct estimates of shocks to firms' funding constraints. The authors argue that those shocks can explain up to half of the variance of US GDP. By contrast, the model here assumes that only the bank faces a capital requirement.
} 
deposits), and so does the loan rate-however, the loan rate spread rises. The Foreign worker responds to the fall in the deposit rate by consuming more, and working less, and hence Foreign GDP falls. (Foreign investment rises slightly, due to the fall in the loan rate.) Country-specific labor supply shocks likewise drive Home and Foreign GDP in opposite directions.

By contrast, banking shocks induce responses of real activity (and of loans) that are common across the two countries. For example, a loan loss in one country lowers the global bank's capital ratio, which triggers a rise in the loan rate spread-the deposit rate falls, while the loan rate rises. In response to this, loans, investment and GDP fall in both countries. A rise in the required capital ratio $\left(\gamma_{t}\right)$ likewise raises the loan rate spread; on impact, this too lowers loans, investment and real activity in both countries. Note also that banking shocks drive the loan spread and output in opposite directions. According to the model variant with independent shocks, an unanticipated US loan loss worth $1 \%$ of steady state quarterly US GDP reduces the bank capital ratio by 14.9 basis points, on impact, and it lowers US and EA quarterly GDP by, respectively, $0.10 \%$ and $0.12 \%$ (on impact). An unanticipated EA loan loss of the same size lowers US and EA GDP by $0.14 \%$ and $0.18 \%$, respectively. Thus, EA GDP is more sensitive to domestic and foreign loss shock than US GDP. A US loan loss lowers EA GDP more than US GDP. An unanticipated increase in the required bank ratio by one percentage point lowers US and EA GDP by $0.10 \%$ and $0.11 \%$, respectively, on impact.

\subsection{Decomposing historical time series (Figures 6 and 7)}

Figure 6 plots the estimated contributions of the banking shocks and of US and EA nonbanking shocks to the historical time series, implied by the model variant with independent shocks. ${ }^{25}$ Thick continuous lines show the historical data; the thin continuous lines indicate the contribution of banking shocks, while the dashed-dotted and dashed lines represent the contributions of US and EA non-banking shocks, respectively.

The historical decomposition yields a picture that is consistent with the variance

\footnotetext{
25 The decomposition is computed at the posterior mode of the estimated parameters. Using smoothed shocks and measurement errors, each historical series can be expressed as the sum of: (i) a 'base' trajectory (dynamic effects of predetermined states in the initial period) plus measurement error; (ii) contributions of each exogenous shock. Figures 6 and 7 shows data and shock contributions.
} 
decompositions. Banking shocks matter more for EA GDP than for US GDP. During the 'Great Recession' of 2007q4-2009q2, banking shocks account for a 1.0 percentage point [1.2 ppt.] fall in US [EA] GDP-i.e. the banking shocks capture 12\% [16\%] of the 8.5 ppt. [7.5 ppt.] fall in US [EA] GDP, relative to trend. Banking shocks also capture 15\% [35\%] of the fall in US [EA] investment, and 19\% [56\%] of the fall in US [EA] employment, during the recession. Thus, more than 1/3 of the fall in EA investment and employment is accounted for by the banking shocks.

In the previous US recession (2001q1-2001q4), banking shocks accounted for $11 \%$ of the fall in US output and investment, and for 21\% [29\%] of the fall in EA output [investment]. During the 1990q3-1991q1 US recession, banking shocks accounted for $6 \%, 10 \%$ and $16 \%$, respectively, of the fall in US GDP, investment and employment (the EA did not experience a recession in 1990-91).

Figure 6 shows that the output components accounted for by the domestic nonbanking shocks track historical US and EA GDP very closely. This result parallels the finding by de Walque et al. (2005) and Le et al. (2010) that domestic macro shocks are the main drivers of US and EA GDP. Foreign non-banking shocks had a stabilizing effect on domestic real activity; eg, during the 2007-09 recession, EA non-banking shocks had a positive influence on US GDP, and thus mitigated the US recession. This reflects the fact that, in the model here, TFP shocks and labor supply shocks are negatively transmitted internationally (see above).

Figure 7 reports historical decompositions implied by the model variant with correlated shocks. That variant attributes larger shares of the drop in real activity during the 2007q4-2009q2 recession to banking shocks, namely 17\% [21\%] of the fall in US [EA] GDP, 24\% [54\%] of the fall in US [EA] investment, and 30\% [79\%] of the reduction in US [EA] employment.

\subsection{The role of the bank capital requirement and of banking shocks}

The presence of an operative bank capital requirement $\phi^{\prime \prime}>0$ is key for the transmission of banking shocks to domestic and foreign real activity. Banking shocks have a negligible effect on real activity, but remain important drivers of loans and the bank capital ratio, when $\phi^{\prime \prime}=0$. (An estimated model variant with $\phi^{\prime \prime}=0$ predicts that banking shocks 
explain merely $0.002 \%$ of the variance of HP filtered GDP and investment, but between $1 / 3$ and 2/3 of the variances of loans and the bank capital ratio.)

Columns (6)-(7) of Table 2 reports posterior parameter estimates for an independent-shocks model variant without an operative bank capital requirement $\left(\phi^{\prime \prime}=0\right)$, and without banking shocks. ${ }^{26}$ That model variant resembles standard International RBC models with incomplete financial markets in which just an unconditional bond can be traded internationally (see, e.g., Baxter and Crucini (1995), Kollmann (1996)). Columns (10)-(11) of Table 3 report the implied business cycle moments.

Table 3 shows that the baseline independent-shocks model (with operative bank capital requirement and banking shocks) generates business cycles moments that are, mostly, closer to the empirical moments than the variant without the operative bank capital requirement (and without banking shocks); see Columns (1) and (10) of Table 3. For example, predicted standard deviations of US and EA GDP in the baseline model (1.14\% and $1.22 \%$, respectively ) are larger than in the structure without the operative bank capital requirement (1.01\%, 0.95\%), and closer to the empirical standard deviations $(1.12 \%, 1.14 \%)$. Note that the independent-shocks model with $\phi^{\prime \prime}=0$ too generates predicted cross-country correlations of GDP (-0.16), investment (-0.10) and employment $(-0.10)$ that are markedly below the empirical cross-country correlations (like the baseline structure). ${ }^{27}$

Model fit can be evaluated using the marginal likelihood. ${ }^{28}$ The log marginal likelihood (LML) of the baseline model with independent shocks is 3300.06, while the LML of the model variant without the operative bank capital constraint and without

\footnotetext{
${ }^{26}$ The priors for parameter (other than $\phi^{\prime \prime}$ ) are the same as in the baseline model. The posterior estimates of most parameters are similar to the estimates in the baseline model.

27 Surprisingly, the predicted cross-country correlations of GDP and employment with $\phi "=0$ (without banking shocks) are slightly higher than in the baseline model with $\phi^{\prime \prime}>0$ (with banking shocks). This is i.a. due to the fact that estimated standard deviations of TFP shocks (which are negatively transmitted across countries) are lower when $\phi^{\prime \prime}=0$. Holding constant the distribution of non-banking shocks (and parameters other than $\phi^{\prime \prime}$ ) at the estimates for the baseline model, but setting $\phi^{\prime \prime}=0$ and eliminating the banking shocks lowers the predicted cross-country correlations of GDP and employment to -0.30 and -0.32 , respectively (compared to -0.26 and -0.24 , respectively in the baseline model).

${ }^{28}$ The marginal likelihood (ML) measures the out-of-sample predictive ability of the model (Geweke (2001)). The MLs reported here were computed using a Laplace approximation (Canova (2007)). The Geweke (1999) harmonic mean estimator, based on parameter draws from the Metropolis algorithm, yields very similar MLs.
} 
banking shocks is 3104.02. This implies a Bayes factor (ratio of posterior odds to prior odds) of $e^{196.04}$ that massively favors the baseline model. The model variant with an operative bank capital requirement, but without banking shocks has a LML of 3105.36; a model variant without an operative bank capital requirement but with banking shocks has a LML of 3212.29. This suggests that both the operative bank capital requirement and the banking shocks help the model capture the joint dynamics of the macro and banking variables used in estimation. The presence of these model ingredients also helps to better explain the 8 US and EA macro variables used in estimation. For these 8 macro variables, the baseline model has a LML of 2041.23, while the model variant without an operative bank capital requirement and without banking shocks has a LML of 2036.88.

Similar findings obtain for the structure with correlated shocks. With correlated shocks, the model variant with an operative bank capital requirement and banking shocks has a LML of 3323.88, while a variant without bank capital requirement and without banking shocks has a LML of 3138.84; in terms of just the 8 US and EA macro variables, the corresponding LMLs are 2229.45 ( $\phi^{\prime \prime}>0$, with banking shocks) and 2075.00 ( $\phi "=0$, no banking shocks), respectively, i.e. the model with the operative bank capital requirement and banking shocks is clearly favored.

\subsection{Further robustness checks}

Panel (a2) of Table 4 reports variance decompositions for an independent-shocks model variant with an operative bank capital requirement, in which the required bank capital ratio is constant, $\gamma_{t}=\gamma$, so that loan losses are the only banking shocks. In that variant, banking shocks explain somewhat greater shares of the variance of real activity than in the baseline model; however, the $\gamma_{t}=\gamma$ variant has a markedly lower LML (3229.48) than the baseline model.

As a further robustness check, I re-estimated the model variant with independent shocks using other empirical measures of the loan rate spread and of bank loans. Panel (a3) of Table 4 reports the resulting estimates of variance shares explained by banking shocks. These variance shares are broadly in the same range as the baseline shares discussed above (Panel (a1)). (Posterior parameter estimates obtained from the alternative data sets are in the same range as the baseline estimates, and are thus not reported) 
In Panel (a3.1) of Table 4, the baseline loan rate spread is replaced by the series 'net percentage of banks increasing spreads of loan rates over cost of funds' (from SLOOS), while Panel (a3.2) uses the Gilchrist-Zakrajšek (2011a) excess bond premium series in lieu of the baseline loan rate spread. The importance of banking shocks in explaining real activity fluctuations rises somewhat when those alternative spread measures are used to estimate the model. (The same result holds when the SLOOS series 'net percentage of banks tightening lending standards' is used instead of the baseline lending spread.) For example, when the Gilchrist-Zakrajšek excess bond premium is used, about 5\% of the variance of US and EA GDP is attributed to banking shocks. ${ }^{29}$

In Panel (a3.3) of Table 4, total bank credit is replaced by US and EA bank loans to the non-financial business sector, while Panel (a3.4) uses Gilchrist and Zakrajšek's (2011b) measure of US 'business lending capacity' in lieu of US total credit. ${ }^{30}$ Figures 4 and 5 plot these series. Business loans are highly positively correlated with total loans, but more volatile, especially in the US. US lending capacity fell earlier and much more sharply than total lending, during the 2007-09 recession. The business lending measures yields smaller variance shares due to banking shocks than the baseline model variant, while the lending capacity measure yields roughly similar variance shares as the baseline variant. $^{31}$

\section{Conclusion}

This paper has estimated a two-country model with a global banking system, using US and Euro Area (EA) data (1990q1-2010q3), and Bayesian methods. The estimated model matches key US and EA business cycle statistics. Empirically, a model version with an

\footnotetext{
${ }^{29}$ As pointed out by a referee, the lending rate spread may be affected by factors that are not captured by the model, such as credit risk, liquidity tensions and banking competition (incorporating these factors into the theory would be a useful task for future research). The fact that the SLOOS index and the GilchristZakrajšek bond premium explain a slightly greater share of the variance of real activity might indicate that these spread measures capture better those other determinants of credit supply.

${ }^{30}$ In the US, many business loans are offered under prior commitment (credit lines); hence, business loans respond with a lag to shocks to bank funding. The Gilchrist and Zakrajšek 'business lending capacity' measure is defined as the sum of loans outstanding and of unused commercial bank lending commitments-the authors argue that this variable is more informative (than loans outstanding) for identifying loan supply shifts (no comparable measure exists for the EA).

${ }^{31}$ I also estimated the model using an alternative measure of the bank capital ratio--the capital ratio of US Securities Brokers and Dealers (instead of the capital ratio of US commercial banks). Results are robust to using this measure. Kollmann and Zeugner (2012) analyze the capital ratio dynamics of different subsectors of the finance industry.
} 
operative bank capital constraint outperforms a structure without such a constraint. Banking shocks account for 3\%-5\% of the unconditional variance of US GDP, and for $4 \%-14 \%$ of the variance of EA GDP. The variance shares of investment accounted for by banking shocks are higher, especially for the EA (20\% or more). Thus, EA real activity depends more on banking shocks than US real activity. US loan losses account for a greater share of the variance of EA real activity than of the variance of US real activity. During the Great Recession (2007-09), banking shocks accounted for about 12\%-20\% of the fall in US and EA GDP, and for more than a third of the fall in EA investment and employment. 


\section{DATA APPENDIX}

\section{A.1 Baseline data set used for estimation}

- US GDP, private consumption (total), investment (all at constant prices): from US National Income and Product Accounts (Bureau of Economic Analysis, BEA); the investment series include private and government investment.

- US employment: 'Total nonfarm payrolls: all employees' (Bureau of Labor Statistics)

- US bank loans: outstanding 'total bank credit' by Commercial Bank, deflated using GDP deflator (from June 2011 Flow of Funds, Table L109).

- US bank capital ratio: (total financial assets-total liabilities)/(total financial assets) for Commercial Banks (from June 2011 Flow of Funds, Table L109).

- US loan rate spread: 'Commercial and industrial loan rates spread over intended federal funds rate' ('All loans' series, Survey of Terms of Business Lending, Table E.2, Federal Reserve Board, June 2011).

- EA GDP, private consumption (total), investment (all at constant prices): from ECB Area-Wide Model (AWM) database $\left(10^{\text {th }}\right.$ update, September 2010).

- EA employment: from AWM database.

- EA bank loans: MFI loans to private sector (from ECB monthly bulletin), deflated using the GDP deflator.

\section{A.2 Other variables (used for estimation of model variants)}

- Excess bond premium: spread between the yield on US commercial bonds and the yield on Treasury bonds, minus expected bond default probabilities, as constructed by Gilchrist and Zakrajšek (2011a) using data for a panel of individual bonds.

- 'Net percentage of banks increasing spreads of loan rates over cost of funds': percentage of banks increasing spreads minus the percentage of banks lowering spreads, from the Senior Loan Officer Opinion Survey on Bank Lending Practices, SLOOS (Federal Reserve Board). SLOOS reports a series (net percentages of banks raising spreads) for loans to 'large and middle-market firms' and one for loans to 'small firms'. The two series are very similar (correlation: 0.95). I use the average of the two series.

- US business loans: outstanding commercial bank loans to the non-financial business sector, constructed by Gilchrist and Zakrajšek (2011b).

- EA business loans: MFI loans to non-financial corporations(NFC), from ECB monthly bulletin, deflated using the GDP deflator.

- US business lending capacity: outstanding commercial bank loans plus unused commercial bank lending commitments (credit lines) to the non-financial business sector, constructed by Gilchrist and Zakrajšek (2011b).

\section{A.3 Other variables (used for model calibration)}

- 'Autonomous spending' $(\mathrm{G})$ : government purchases plus net exports to third countries (deflated using GDP deflator). Data sources: AWM, BEA and ECB monthly bulletin.

- Investment efficiency: measured as ratio of CPI to Gross Investment Deflator (BEA and AWM).

All series are quarterly and seasonally adjusted (when relevant) 


\section{REFERENCES}

Adolfson, M., S. Laséen, J. Lindé and M. Villani, 2007. Bayesian Estimation of an Open Economy DSGE Model with Incomplete Pass-Through. Journal of International Economics 72, 481-511.

Aikman, D. and M. Paustian, 2006. Bank Capital, Asset Prices and Monetary Policy. Working Paper No. 305, Bank of England.

An, S. and F. Schorfheide, 2007. Bayesian Analysis for DSGE Models. Econometric Reviews 26, 113-172.

Andreasen, M., J. Sondergaard and M. Paustian, 2010. Portfolio Linkages, Financial Shocks and International Business Cycles. Working Paper, Bank of England.

Backus. D., P. Kehoe, and F. Kydland, 1992, International Real Business Cycles. Journal of Political Economy 100, 745-775.

Baxter, M., and M. Crucini, 1995. Business Cycles and the Asset Structure of Foreign Trade. International Economic Review 36, 821-54

Boivin, J., and M. Giannoni, 2006. DSGE Models in a Data Rich Environment. Working Paper No. 12772, National Bureau of Economic Research.

Brunnermeier, M. and Y. Sannikov, 2010. A Macroeconomic Model with a Financial Sector. Working Paper, Princeton University.

Canova, F., 2007. Methods for Applied Macroeconomic Research. Princeton University Press, Princeton.

Christiano, L., M. Eichenbaum and C. Evans, 2005. Nominal Rigidities and the Dynamic Effects of a Shock to Monetary Policy. Journal of Political Economy 113, 1-45.

Coeurdacier, N., R. Kollmann and P. Martin, 2010. International Portfolios, Capital Accumulation and the Dynamics of Capital Flows. Journal of International Economics 80, 100-112.

Correa, R., H. Sapriza and A. Zlate, 2010. International Banks, the Interbank Market, and the Cross-Border Transmission of Business Cycles. Working Paper, International Finance Section, Federal Reserve Board.

Davis, S., 2010. The Adverse Feedback Loop and the Effects of Risk in both the Real and Financial Sectors. Working Paper No. 66, Globalization and Monetary Policy Institute.

de Antonio Liedo, D., 2011. What are Shocks Capturing in DSGE Modeling? Noise Versus Structure. Working Paper, National Bank of Belgium.

Dedola, L. and G. Lombardo, 2012. Financial Frictions, Financial Integration and the International Propagation of Shocks., Economic Policy, 319-359.

Del Negro, M., G. Eggertsson, A. Ferrero, A. and N. Kiyotaki, 2011. The Great Escape? A Quantitative Evaluation of the Fed's Liquidity Facilities. Staff Report no. 520, Federal Reserve Bank of New York.

Devereux, M. and A. Sutherland, 2011. Evaluating International Financial Integration Under Leverage Constraints. European Economic Review 55, 427-442.

Dewachter, H. and R. Wouters, 2012. Endogenous Risk in a DSGE Model with CapitalConstrained Financial Intermediaries. Working Paper 235, National Bank of Belgium.

de Walque, G, O. Pierrard and A. Rouabah, 2010. Financial (In)Stability, Supervision and Liquidity Injection: A Dynamic General Equilibrium Approach. Economic Journal 120, 1234-1261.

de Walque, G., F. Smets and R. Wouters, 2005. An Estimated Two-Country DSGE Model for the Euro Area and the US Economy. Working Paper, National Bank of Belgium. 
Fisher, J., 2006. The Dynamic Effects of Neutral and Investment-Specific Technology Shocks. Journal of Political Economy 114, 413-52.

Freixas, X. and J.-C. Rochet, 2008. The Microeconomics of Banking. MIT Press, Cambridge.

Galí, J., F. Smets and R. Wouters, 2011. Unemployment in an Estimated New Keynesian Model. Working Paper 17084, National Bureau of Economic Research.

Gerali, Andrea, Stefano Neri, Luca Sessa and Federico Signoretti. 2010. Credit and Banking in a DSGE Model of the Euro Area. Journal of Money, Credit and Banking 42, 107-141.

Gertler, M. and P. Karradi, 2011. A Model of Unconventional Monetary Policy. Journal of Monetary Economics 58, 17-34

Gertler, M. and N. Kiyotaki, 2011. Financial Intermediation and Credit Policy in Business Cycle Analysis. In: Handbook of Monetary Economics (B. Friedman and M. Woodford, eds.), Vol. 3A, 547-599, Elsevier: Amsterdam.

Geweke, J., 1999. Using Simulation Methods for Bayesian Econometric Models: Inference, Development and Communication. Econometric Reviews 18, 1-126.

---------, 2001. Bayesian Econometrics and Forecasting. Journal of Econometrics 100, 11-15.

Gilchrist, S. and E. Zakrajšek, 2011a. Credit Spreads and Business Cycle Fluctuations. Working Paper No. 17201, National Bureau of Economic Research.

---------, 2011b. Bank Lending and Credit Supply Shocks, Working Paper, Boston University.

He, Z. and A. Krishnamurthy, 2012. A Macroeconomic Framework for Quantifying Systemic Risk. Working Paper, University of Chicago and Northwestern University.

Helbling, T., R. Huidrom, M.A. Kose and C. Otrok, 2011. European Economic Review 55, 340-353.

Huizinga, H. and L. Laeven, 2009. Accounting Discretion of Banks During a Financial Crisis. Discussion Papers 7381, Centre for Economic Policy Research.

Iacoviello, M., 2010. Financial Business Cycles. Working Paper, Boston College.

Ireland, P., 2004. A Method for Taking Models to the Data. Journal of Economic Dynamics and Control 28, 1205-1226.

Jacob, P. and G. Peersman, 2011. Dissecting the Dynamics of the US Trade Balance in an Estimated Equilibrium Model. Working Paper, Ghent University.

Jermann, U. and V. Quadrini, 2012. Macroeconomic Effects of Financial Shocks, American Economic Review 102, 238-271.

Justiniano, A, and B. Preston, 2010. Can Structural Small Open Economy Models Account for the Influence of Foreign Disturbances? Journal of International Economics 81, 61-74.

Justiniano, A, G. Primiceri and A. Tambalotti, 2008. Investment Shocks and Business Cycles. Journal of Monetary Economics 57, 132-145.

Kamber, G. and C. Thoenissen, 2011. Financial Intermediation and the International Business Cycle: the Case of a Small Country with Big Risk. CAMA Working Paper 22/2011.

Kollmann, R., 1991. Essays on International Business Cycles. PhD Dissertation, University of Chicago.

Kollmann, R., 1996. Incomplete Asset Markets and the Cross-Country Consumption Correlation Puzzle, Journal of Economic Dynamics and Control 20, 945-962. 
Kollmann, R., Z. Enders and G. Müller, 2011. Global Banking and International Business Cycles. European Economic Review 55, 407-426.

Kollmann, R. and S. Zeugner, 2012. Leverage as a Predictor of Real Activity and Volatility. Journal or Economic Dynamics and Control 36, 1267-1283.

Kollmann, R., 2012. Limited Asset Market Participation and the Consumption-Real Exchange Rate Anomaly. Canadian Journal of Economics 45, 566-584.

Kollmann, R., W. Roeger and J. in't Veld, 2012. Fiscal Policy in a Financial Crisis: Standard Policy versus Bank Rescue Measures. American Economic Review (Papers and Proceedings) 102, 1-7.

Le, V., D. Meenagh, P. Minford and M. Wickens, 2010. Two Orthogonal Continents? Testing a Two-Country DSGE Model of the US and the EU Using Direct Inference. Open Economies Review 21, 23-44.

Lipinsky, F., 2012. Imbalances in the Euro Area and Macroprudential Policies, Working Paper, London Business School.

Meh, C.A., Moran, K., 2010. The Role of Bank Capital in the Propagation of Shocks. Journal of Economic Dynamics and Control 34, 555-576.

Mendicino, C. and M. Punzi, 2011. Stabilization Policy and Boom-Bust Cycles: Monetary and Macro-Prudential Rules. Bank of Portugal Economic Bulletin 17, 97105.

Nguyen, H., 2011. International Crisis Transmission and Asymmetric Recoveries. Working Paper, World Bank.

Nolan, C. and C. Thoenissen, 2009. Financial Shocks and the US Business Cycle. Journal of Monetary Economics 56, 596-604.

Perri, F. and V. Quadrini, 2011. International Recessions. Working Paper, University of Minnesota.

Rabanal, P. and V. Tuesta, 2006. Euro-Dollar Real Exchange Rate Dynamics in an Estimated Two-Country Model: What is Important and What is Not? Working Paper 06/177, International Monetary Fund.

Schmitt-Grohé, S. and M. Uribe, 2003. Closing Small Open Economy Models. Journal of International Economics 61, 163-185.

Smets, F. and R. Wouters, 2007. Shocks and Frictions in US Business Cycles: A Bayesian DSGE Approach. American Economic Review 97, 586-660.

Ueda, K., 2010. Banking Globalization and International Business Cycles. Working Paper, Institute for Monetary and Economic Studies, Bank of Japan.

Van den Heuvel, S., 2008. The Welfare Cost of Bank Capital Requirements. Journal of Monetary Economics 55, 298-320.

Van Wincoop, E., 2011. International Contagion Through Leveraged Financial Institutions. Working Paper, University of Virginia. 


\section{(a) Standard deviations (in \%, diagonal) and cross-correlations (off-diagonal elements)}

US TFP

EA TFP

US Ieff

EA Ieff

US G

EA G

US LabS

EA LabS

$\begin{array}{cccl}\text { US TFP } & \text { EA TFP } & \text { US Ieff } & \text { EA Ieff } \\ 1.34 & 0.51 & 0.27 & 0.20 \\ & 1.68 & 0.53 & 0.63 \\ & & 2.76 & 0.84 \\ & & & 1.74\end{array}$

(b) Autocorrelations

US TFP

0.93
EA TFP
US Ieff
EA Ieff

US G

EA G

US LabS EA LabS

$-0.71 \quad-0.24$

$-0.53 \quad-0.36$

$-0.75$

0.41

$\begin{array}{ll}-0.88 & 0.23\end{array}$

$-0.12$

0.16

$-0.48$

0.28

$-0.27$

0.37

$-0.57$

0.58

6.58

$-0.13$

0.73

0.02

2.49

$-0.17$

0.71

3.12

$-0.02$

1.83

(c) Standard deviations of innovations (in \%)

$\begin{array}{cccccccc}\text { US TFP } & \text { EA TFP } & \text { US Ieff } & \text { EA Ieff } & \text { US G } & \text { EA G } & \text { US LabS EA LabS } \\ 0.48 & 0.48 & 0.64 & 0.31 & 2.61 & 1.43 & 0.61 & 0.48\end{array}$

Note: The Table reports sample moments of empirical measures of US and Euro Area (EA) 'non-banking' forcing variables (in linearly detrended log form). Panel (a) reports \% standard deviations (on main diagonal), and crosscorrelations (off-diagonal elements). Panel (b) reports first-order autocorrelations. Panel (c) reports \% standard deviations of residuals of univariate $\operatorname{AR}(1)$ equations fitted to each variable.

TFP: total factor productivity $(\theta)$; Ieff: investment efficiency $(\Xi)$; G: autonomous spending (government consumption plus net exports to third countries); LabS: Labor supply shock $\left(\Psi^{N}\right)$.

Log TFP is estimated as $\ln \left(Y_{t}\right)-0.7 \ln \left(N_{t}\right)$ where $Y_{t}$ and $N_{t}$ are GDP and employment, respectively. The estimate of investment efficiency is the ratio of the CPI to the investment deflator. The estimate of the log labor supply shock is $\ln \left(Y_{t}\right)-\ln \left(N_{t}\right)-\ln \left(C_{t}\right)$, where $C_{t}$ is private consumption. 


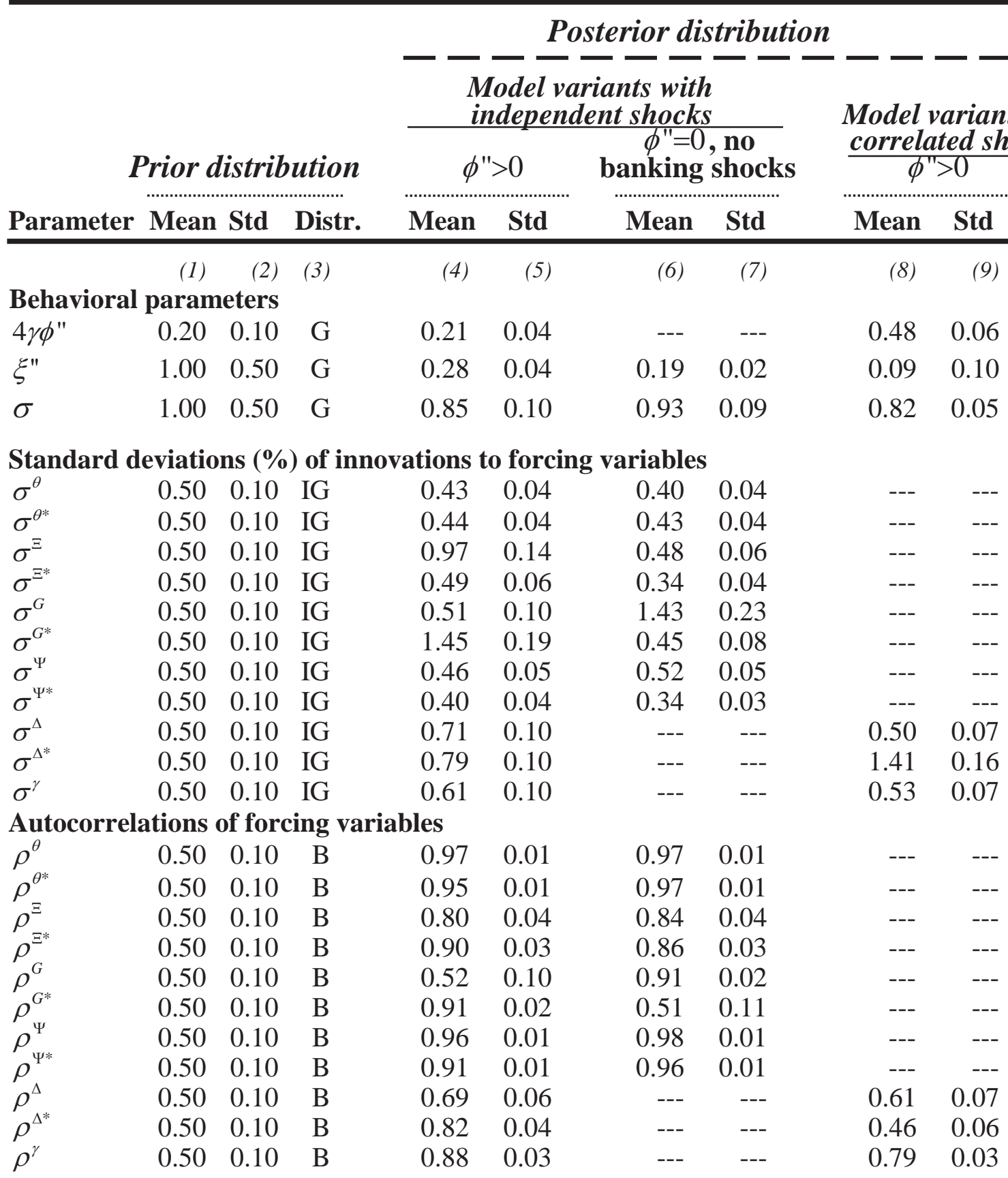

Feedback parameters of loan losses and required capital ratio to GDP
$\vartheta^{\Delta}$
$\begin{array}{lll}0.00 & 0.10 & \mathrm{~N}\end{array}$
--- ---
---
$0.07 \quad 0.02$
$0.07 \quad 0.02$

Standard deviations (\%) of measurement errors

\begin{tabular}{llllllllll} 
GDP US & 0.79 & 0.16 & IG & 0.46 & 0.07 & 0.39 & 0.04 & 0.40 & 0.04 \\
GDP EA & 0.54 & 0.11 & IG & 0.30 & 0.04 & 0.31 & 0.04 & 0.30 & 0.04 \\
C US & 0.78 & 0.16 & IG & 0.63 & 0.09 & 0.39 & 0.04 & 0.58 & 0.07 \\
C EA & 0.44 & 0.09 & IG & 0.32 & 0.04 & 0.31 & 0.04 & 0.39 & 0.06 \\
I US & 3.15 & 0.63 & IG & 2.86 & 0.41 & 4.99 & 0.38 & 3.41 & 0.34 \\
I EA & 1.33 & 0.26 & IG & 0.85 & 0.11 & 0.78 & 0.10 & 0.94 & 0.13 \\
N US & 0.47 & 0.09 & IG & 0.41 & 0.05 & 0.38 & 0.04 & 0.46 & 0.06 \\
N EA & 0.45 & 0.09 & IG & 0.29 & 0.04 & 0.25 & 0.03 & 0.29 & 0.04 \\
& & & & & \multicolumn{7}{c}{35} & & & &
\end{tabular}


Table 2.-- continued

\begin{tabular}{|c|c|c|c|c|c|c|c|c|}
\hline Loans US & 0.85 & 0.17 IG & 0.88 & 0.09 & 0.96 & 0.08 & 0.90 & 0.08 \\
\hline Loans EA & 1.10 & $0.22 \quad \mathrm{IG}$ & 0.49 & 0.06 & 2.86 & 0.21 & 0.48 & 0.06 \\
\hline Bnk cap.ratic & o 0.21 & 0.04 IG & 0.45 & 0.06 & 0.75 & 0.05 & 1.27 & 0.12 \\
\hline Loan spread & 0.03 & 0.01 IG & 0.02 & 0.00 & 0.09 & 0.01 & 0.02 & 0.00 \\
\hline
\end{tabular}

Log marginal likelihood

3300.06

3104.02

3323.88

Notes: Cols. (1) and (2) shows the means and standard deviations of the prior distribution for model parameters listed in the leftmost Column. Col. (3) indicates the distribution function of the prior (B: Beta; G: Gamma; IG: Inverted Gamma; N: Normal).

Cols. (4)-(9): statistics of posterior parameter distribution (means, standard deviations), for different model variants.

Cols. (4)-(5): model variant with independent forcing variables, operative bank capital requirement $(\phi$ ">0) and 'banking shocks'.

Cols. (6)-(7): model variant with independent shocks, no operative bank capital requirement $(\phi$ " $=0)$, no 'banking shocks'.

Cols. (8)-(9): model variant with correlated shocks, operative bank capital requirement $(\phi$ ">0) and 'banking shocks'

Entries reported as "---' in Cols. (4)-(7) represent parameters of the model variant with independent shocks that are set at zero.

Entries reported as "---' in Cols. (8)-(9) represent parameters of the model variant with correlated shocks that are calibrated; specifically, I set the autocorrelations of the 8 non-banking forcing variables, and the covariance matrix of these variables, equal to the sample autocorrelations and sample covariance matrix of empirical measures of the non-banking shocks (1990q1-2010q3), respectively (from Table 1); see Section 3.2.

Parameter definitions:

$4 \gamma \phi^{\prime \prime}$ : sensitivity of loan rate spread to bank capital ratio; a 1 percentage point increase in the bank capital ratio lowers the lending rate spread by $4 \gamma \phi^{\prime \prime}$ percentage points ( $\gamma$ is the steady state bank capital requirement).

$\xi ":$ curvature of investment cost function.

$\sigma$ : coefficient of relative risk aversion

$\sigma^{z}, \rho^{z}$ : standard deviation of innovation to forcing variable ' $\mathrm{z}$ ', and autocorrelation of ' $\mathrm{z}$ ', with $\mathrm{z}$ representing the following shocks-$\theta, \theta^{*}$ : Home and Foreign TFP; $\Xi, \Xi^{*}$ : Home and Foreign investment efficiency; $G, G^{*}$ : government purchases;

$\Psi, \Psi^{*}$ : Home and Foreign labor supply; $\Delta, \Delta^{*}$ : Home and Foreign loan loss; $\gamma$ : required bank capital ratio.

$\vartheta^{\Delta}\left[\vartheta^{\gamma}\right]$ : feedback coefficient of Home and Foreign loan loss [required bank capital ratio] to GDP; see equations (10),(11).

The estimation uses quarterly time series on 12 time series: US and EA GDP, consumption, investment, employment and real loans; the US commercial bank lending rate spread and the US commercial bank capital ratio. The loan spread and the capital ratio are demeaned; other empirical variables are linearly detrended in log form. See Figure 1 for data plots and Data Appendix for definitions of variables and data sources. Sample period: 1990q1-2010q3 (83 periods).

Posterior distributions are computed using the Random Walk Metropolis algorithm (250,000 draws of which the first 50,000 were discarded). 


\begin{tabular}{|c|c|c|c|c|c|c|c|c|c|c|c|c|c|c|c|}
\hline \multirow[b]{3}{*}{ Shocks: } & \multicolumn{11}{|c|}{ Model variants with independent shocks } & \multirow{2}{*}{\multicolumn{3}{|c|}{$\begin{array}{l}\text { Model variant with } \\
\text { correlated shocks } \\
\phi ">0 \\
\end{array}$}} & \multirow[b]{3}{*}{ Data } \\
\hline & \multirow[b]{2}{*}{ All } & \multirow[b]{2}{*}{ NonBk } & \multirow[b]{2}{*}{ Bnk } & \multicolumn{3}{|c|}{$\frac{\phi^{\prime \prime}>0}{\text { Invest. }}$} & \multicolumn{3}{|c|}{ Loan } & \multicolumn{2}{|c|}{$\begin{array}{c}\phi "=0, \text { no } \\
\text { banking shocks }\end{array}$} & & & & \\
\hline & & & & TFP & Eff. & G & LabS & Loss & $\gamma$ & $\overline{\text { All }}$ & NonBk & $\overline{\text { All }}$ & NonBk & Bnk & \\
\hline & (1) & (2) & (3) & (4) & (5) & (6) & (7) & (8) & (9) & (10) & (11) & (12) & (13) & (14) & (15) \\
\hline \multicolumn{16}{|c|}{ (a) US moments } \\
\hline \multicolumn{16}{|c|}{ Standard deviations (in \%) } \\
\hline GDP & 1.14 & 1.03 & 0.20 & 0.78 & 0.23 & 0.09 & 0.62 & 0.18 & 0.08 & 1.01 & 0.94 & 1.30 & 1.20 & 0.31 & 1.12 \\
\hline Consumption & 0.93 & 0.72 & 0.07 & 0.57 & 0.14 & 0.04 & 0.40 & 0.07 & 0.03 & 0.79 & 0.69 & 1.33 & 1.20 & 0.14 & 0.92 \\
\hline Investment & 4.58 & 3.38 & 1.13 & 1.07 & 3.11 & 0.12 & 0.80 & 1.04 & 0.43 & 5.52 & 2.70 & 5.32 & 3.83 & 1.73 & 5.08 \\
\hline Employment & 1.13 & 1.02 & 0.28 & 0.41 & 0.29 & 0.12 & 0.88 & 0.26 & 0.11 & 0.96 & 0.89 & 1.15 & 0.97 & 0.43 & 1.15 \\
\hline Loans & 1.73 & 1.03 & 1.10 & 0.20 & 0.99 & 0.07 & 0.16 & 1.10 & 0.08 & 1.20 & 0.76 & 1.50 & 0.96 & 0.78 & 1.88 \\
\hline Bank cap ratio & 0.66 & 0.03 & 0.51 & 0.01 & 0.03 & 0.00 & 0.01 & 0.49 & 0.12 & 0.72 & 0.02 & 1.30 & 0.07 & 0.45 & 0.49 \\
\hline Loan spread & 0.21 & 0.01 & 0.19 & 0.00 & 0.01 & 0.00 & 0.00 & 0.10 & 0.17 & 0.37 & 0.00 & 0.39 & 0.12 & 0.36 & 0.19 \\
\hline \multicolumn{16}{|c|}{ Correlations with domestic GDP } \\
\hline Consumption & 0.56 & 0.80 & -0.57 & 0.89 & -0.43 & -0.99 & 0.85 & -0.52 & -0.84 & 0.72 & 0.88 & 0.76 & 0.93 & -0.86 & 0.89 \\
\hline Inves & 0.31 & .40 & 0.99 & 0.87 & 0.38 & -0.92 & 0.82 & 0.99 & 0.99 & 0.27 & 0.59 & 0.62 & 0.82 & 0.99 & 0.92 \\
\hline Employment & 0.74 & 0.85 & 0.98 & 0.85 & 0.93 & 0.99 & 0.99 & 0.98 & 0.99 & 0.72 & 0.84 & 0.79 & 0.90 & 0.99 & 0.79 \\
\hline Loans & 0.14 & 0.18 & 0.41 & 0.23 & 0.58 & -0.03 & 0.17 & 0.42 & 0.76 & 0.13 & 0.23 & 0.31 & 0.44 & 0.39 & 0.48 \\
\hline Bank c & 0.09 & -0.21 & 0.73 & -0.20 & -0.59 & 0.06 & -0.22 & 0.79 & 0.33 & -0.01 & -0.17 & 0.03 & -0.64 & 0.82 & 0.19 \\
\hline Loan spread & -0.11 & 0.22 & -0.72 & 0.20 & 0.64 & 0.09 & 0.23 & -0.79 & -0.97 & 0.00 & 0.15 & -0.02 & 0.34 & -0.82 & -0.52 \\
\hline
\end{tabular}

\section{(b) EA moments}

\section{Standard deviations (in \%)}

\begin{tabular}{|c|c|c|c|c|c|c|c|c|c|c|c|c|c|c|c|}
\hline GDP & 1.22 & 1.16 & 0.24 & 0.89 & 0.34 & 0.22 & 0.62 & 0.22 & 0.08 & 0.95 & 0.90 & 0.88 & 0.77 & 0.33 & 1.14 \\
\hline Consumption & 0.73 & 0.66 & 0.11 & 0.55 & 0.17 & 0.10 & 0.30 & 0.10 & 0.03 & 0.69 & 0.63 & 0.91 & 0.82 & 0.16 & 0.77 \\
\hline Investment & 2.47 & 2.02 & 1.17 & 1.11 & 1.55 & 0.12 & 0.67 & 1.09 & 0.42 & 2.33 & 2.20 & 2.46 & 1.46 & 1.79 & 2.87 \\
\hline Employment & 1.22 & 1.13 & 0.34 & 0.46 & 0.46 & 0.31 & 0.87 & 0.32 & 0.11 & 0.80 & 0.77 & 0.94 & 0.77 & 0.47 & 0.70 \\
\hline Loans & 1.10 & 0.36 & 0.93 & 0.06 & 0.35 & 0.01 & 0.07 & 0.93 & 0.07 & 2.78 & 0.37 & 1.10 & 0.29 & 0.95 & 2.08 \\
\hline Bank cap ratio & 0.51 & 0.03 & 0.51 & 0.01 & 0.03 & 0.00 & 0.01 & 0.49 & 0.12 & 0.03 & 0.03 & 0.46 & 0.07 & 0.46 & 0.49 \\
\hline Loan spread & 0.21 & 0.01 & 0.19 & 0.00 & 0.01 & 0.00 & 0.00 & 0.10 & 0.17 & 0.37 & 0.00 & 0.39 & 0.12 & 0.36 & 0.37 \\
\hline \multicolumn{16}{|c|}{ Correlations with domestic GDP } \\
\hline Consumption & 0.61 & 0.74 & -0.80 & 0.95 & -0.87 & -0.99 & 0.90 & -0.80 & -0.84 & 0.74 & 0.87 & 0.47 & 0.69 & -0.92 & 0.83 \\
\hline Investment & 0.51 & 0.53 & 0.99 & 0.97 & -0.24 & 0.94 & 0.94 & 0.99 & 0.99 & 0.56 & 0.63 & 0.56 & 0.55 & 0.99 & 0.93 \\
\hline Employment & 0.84 & 0.88 & 0.99 & 0.96 & 0.98 & 1.00 & 1.00 & 0.99 & 0.99 & 0.72 & 0.79 & 0.59 & 0.57 & 0.99 & 0.83 \\
\hline Loans & 0.12 & 0.10 & 0.53 & 0.41 & 0.11 & -0.12 & 0.18 & 0.55 & 0.83 & 0.03 & 0.21 & 0.24 & 0.17 & 0.63 & 0.62 \\
\hline Bank cap ratio & 0.14 & -0.15 & 0.75 & -0.27 & -0.19 & 0.46 & -0.22 & 0.80 & 0.34 & -0.12 & -0.13 & 0.25 & -0.49 & 0.85 & -0.01 \\
\hline Loan spread & -0.13 & 0.15 & -0.69 & 0.23 & 0.29 & -0.33 & 0.13 & -0.80 & -0.97 & 0.00 & 0.19 & -0.15 & 0.49 & -0.81 & -0.91 \\
\hline \multicolumn{16}{|c|}{ (c) Cross-country correlations } \\
\hline GDP & -0.26 & -0.34 & 0.99 & -0.39 & 0.28 & 0.87 & -0.47 & 0.99 & 0.99 & -0.16 & -0.18 & 0.45 & 0.45 & 0.99 & 0.56 \\
\hline Consumption & 0.24 & 0.34 & 0.43 & 0.28 & 0.81 & 0.94 & 0.39 & 0.38 & 0.99 & 0.11 & 0.14 & 0.75 & 0.91 & 0.92 & 0.39 \\
\hline Investment & -0.02 & -0.23 & 1.00 & 0.26 & -0.44 & -0.90 & 0.40 & 1.00 & 0.99 & -0.10 & -0.22 & 0.31 & 0.17 & 0.99 & 0.45 \\
\hline Employment & -0.24 & -0.36 & 0.99 & -0.92 & 0.56 & 0.90 & -0.47 & 0.99 & 0.99 & -0.10 & -0.12 & -0.01 & -0.29 & 0.99 & 0.53 \\
\hline Loans & 0.10 & -0.39 & 0.34 & -0.04 & -0.40 & -0.46 & -0.58 & 0.34 & 0.81 & -0.03 & -0.34 & 0.08 & -0.72 & 0.44 & 0.64 \\
\hline Loan spread & 1.00 & 1.00 & 1.00 & 1.00 & 1.00 & 1.00 & 1.00 & 1.00 & 1.00 & 1.00 & 1.00 & 1.00 & 1.00 & 1.00 & 0.79 \\
\hline
\end{tabular}

Note: Moments of HP filtered model variables (computed for posterior mode of model parameters) are shown. The bank capital ratio is expressed in factional units. The loan rate spread is in fractional units per annum. Other variables are normalized by steady state values.

Cols. (1)-(11) pertain to model variants with independent shocks. Cols. (1)-(9): model variant with operative bank capital requirement $\left(\phi^{\prime \prime}>0\right)$ and 'banking shocks'. Col. (1) ['All'] assumes all 11 joint shocks and measurement error. In Cols. (2)-(9), subsets of shocks used in isolation, without measurement error (model not re-estimated). Col. (2) ['NonBk']: just 8 'non-banking' shocks; Col. (3) ['Bnk']: just 3 'banking' shocks. Col. (4) ['TFP']: just Home and Foreign TFP shocks; Col. (5) ['Invest.Eff']: just investment efficiency shocks; Col. (6) ['G']: just government purchases shocks; Col.(7) ['LabS']: just labor supply shocks; Col.(8) ['Loan Loss']: just loan loss shocks; $\quad$ Col. (9) [' $\gamma$ ']: just shock to required bank capital ratio. Cols. (10)-(11): model variant without operative bank capital requirement $\left(\phi^{\prime \prime}=0\right)$ and without banking shocks. Col. (10) ['All']: all non-banking shocks and measurement error; Col. (11) ['NonBk']: just non-banking shocks, no measurement error.

Cols. (12)-(14): model variant with correlated shocks, operative bank capital requirement $\left(\phi^{\prime \prime}>0\right)$ and banking shocks. Col. (12) [“All’]: all 11 shocks and measurement error. Col. (13) ['NonBk']: just 8 'non-banking' shocks; Col. (14) ['Bnk']: just 3 'banking' shocks.

Col. (15): empirical moments of HP filtered data (GDP, consumption, investment, employment and loans are logged before filtering). Statistics for the EA bank capital ratio use the US capital ratio as a proxy. Sample: 1990q1-2010q3 (except for EA loan spread: 2003q1-10q3). 


\begin{tabular}{|c|c|c|c|}
\hline GDP & Consumption & Investment & Employmen \\
\hline "Ё̈ & $\mathbf{E}$ & "ЕÄ & \\
\hline
\end{tabular}
(1) (2)
(3) (4)
(5) (6)
(7) (8)
(9) (10)

Bank Cap. Loan

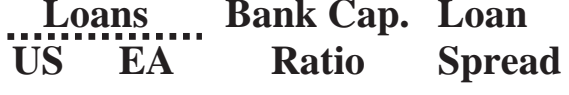

(a) Model variants with independent forcing processes

(a1) Baseline specification, $\phi^{\prime \prime}>0 \quad\left[4 \gamma \phi^{\prime \prime}=0.21\right.$; LML $\left.=3300.06\right]$

$\begin{array}{lrrrrrrrrrrrr}\text { NonBk } & 82.40 & 90.56 & 59.75 & 81.71 & 54.70 & 67.23 & 82.19 & 87.21 & 35.70 & 10.84 & 0.23 & 0.11 \\ \text { NonBk }^{\text {US }} & 73.46 & 9.31 & 56.52 & 6.23 & 53.66 & 5.20 & 64.46 & 17.94 & 32.76 & 1.32 & 0.16 & 0.08 \\ \text { NonBk }^{\text {AA }} & 8.94 & 81.24 & 3.23 & 75.47 & 1.03 & 62.03 & 17.73 & 69.26 & 2.93 & 9.51 & 0.07 & 0.03 \\ \text { Bank } & 3.08 & 3.99 & 0.59 & 2.21 & 6.06 & 22.62 & 6.28 & 7.81 & 41.04 & 72.01 & 59.68 & 84.67 \\ \Delta^{U S} & 0.69 & 0.98 & 0.37 & 0.10 & 1.43 & 5.40 & 1.50 & 1.89 & 37.88 & 0.71 & 20.21 & 8.59 \\ \Delta^{E A} & 1.88 & 2.50 & 0.15 & 1.98 & 3.73 & 14.22 & 3.82 & 5.05 & 2.89 & 70.90 & 36.15 & 15.36 \\ \gamma & 0.50 & 0.50 & 0.07 & 0.13 & 0.89 & 2.99 & 0.95 & 0.87 & 0.26 & 0.38 & 3.31 & 60.71\end{array}$

(a2) Model version with constant required bank capital ratio, $\gamma_{t}=\gamma \quad$ [4 $\gamma \phi "=0.69$; LML $\left.=3229.48\right]$

$\begin{array}{lrrrrrrrrrrrr}\text { NonBk } & 78.57 & 87.09 & 58.21 & 82.75 & 46.36 & 58.24 & 76.30 & 81.03 & 34.75 & 11.97 & 0.08 & 0.45 \\ \text { Bank } & 5.87 & 6.98 & 0.84 & 2.52 & 8.83 & 32.79 & 11.91 & 13.75 & 34.87 & 63.89 & 16.94 & 85.72\end{array}$

(a3) Estimates based on alternative loan rate spread and bank loans data

(a3.1) Loan rate spread replaced by survey of loan officer spread measure [ $4 \gamma \phi "=0.21 ; \mathrm{LML}=3275.21]$
NonBk 81.2690 .16
62.1480 .49
54.7869 .82
81.3886 .55
35.0012 .45
0.27
0.09
Bank $\quad 3.45 \quad 4.37$
$0.72 \quad 2.40$
6.1921 .11
$6.98 \quad 8.48$
42.3870 .02
65.14
90.17

(a3.2) Loan spread replaced by Gilchrist-Zakrajsek excess bond premium [4 $\left.\gamma \phi^{\prime \prime}=0.30 ; \mathrm{LML}=3239.21\right]$

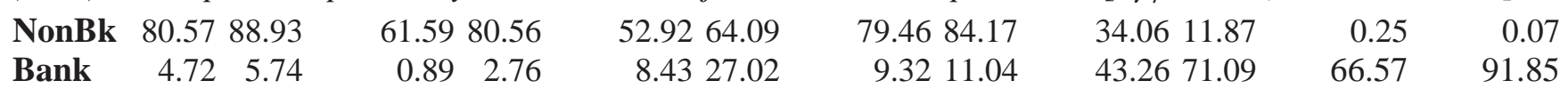

(a3.3) Total bank loans replaced by business loans [ $4 \gamma \phi^{\prime \prime}=0.18 ; \mathrm{LML}=3080.35$ ]

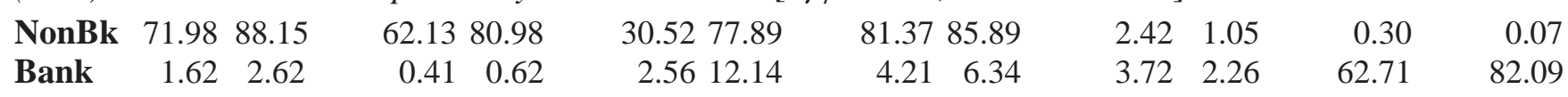

(a3.4) US business lending capacity; EA business loans [4 $\gamma \phi "=0.10 ; \mathrm{LML}=3090.46]$

\begin{tabular}{|c|c|c|c|c|c|c|}
\hline & .03 & 50.0282 .70 & 48.7261 .36 & 84.2387 .32 & $12.09 \quad 4.64$ & 0.01 \\
\hline Ban & $.65 \quad 3.82$ & $\begin{array}{ll}0.87 & 2.73\end{array}$ & 9.5927 .60 & $5.26 \quad 7.82$ & 70.1678 .63 & 12.23 \\
\hline
\end{tabular}

(b) Model variant with correlated forcing variables [ $4 \gamma \phi "=0.48$; $L M L=3323.88]$

$\begin{array}{lrrrrrrrrrrrr}\text { NonBk } & 85.70 & 75.11 & 81.56 & 80.21 & 51.96 & 34.90 & 71.48 & 66.83 & 40.48 & 7.00 & 0.30 & 10.40 \\ \text { Bank } & 5.54 & 14.21 & 1.04 & 3.14 & 10.60 & 52.99 & 14.12 & 24.77 & 27.27 & 75.79 & 12.23 & 84.80 \\ \Delta^{U S} & 0.75 & 2.15 & 0.23 & 0.27 & 1.50 & 7.79 & 1.98 & 3.69 & 22.59 & 0.70 & 1.52 & 3.27 \\ \Delta^{E A} & 3.31 & 8.62 & 0.53 & 2.27 & 6.34 & 32.52 & 8.45 & 15.35 & 3.29 & 73.76 & 8.49 & 19.80 \\ \gamma & 1.47 & 3.42 & 0.27 & 0.59 & 2.76 & 12.67 & 3.68 & 5.72 & 1.38 & 1.33 & 2.22 & 61.72\end{array}$

Note: This Table reports shares of the variances of endogenous variables (HP-filtered) that are accounted for by different types of shocks (based on model predictions evaluated at posterior modes of model parameters).

Panel (a) pertains to variants of the model with independent forcing variables.

(a1): baseline model; (a2): model with constant required bank capital ratio;

(a3): estimates of the model based on alternative measures of spreads and loans. (a3.1): baseline loan rate spread replaced by 'net percentage of banks increasing spreads of loan rates over cost of funds' from the US senior loan officer opinion survey, SLOOS. (a3.2): baseline loan rate spread replaced by the Gilchrist and Zakrajsek (2011a) excess bond premium series. (a3.3): the baseline loan series for US and EA replaced by loans to the non-financial business sector. (a3.4): baseline US loan series replaced by US 'business lending capacity' measure of Gilchrist and Zakrajsek (2011b); baseline EA loan series replaced by EA bank lending to the non-financial business sector.

Panel (b) pertains to the model variant with correlated forcing variables. 
Table 4-ctd.

The rows labeled 'NonBk' show shares of the variances of HP filtered variables accounted by the 'non-banking' forcing variables: US and Euro Area [EA] TFP, investment efficiency, government purchases and labor supply shocks).

Rows labeled 'NonBk ${ }^{\mathrm{US}}$, ['NonBk${ }^{\mathrm{EA}}$ ']: variance shares accounted for by US [EA] non-banking shocks.

Rows labeled 'Bank': variances shares accounted by the 3 banking shocks.

Rows labeled ' $\Delta^{U S}$, , ' $\Delta^{E A}$, and ' $\gamma$ ': variance shares accounted for by shocks to Home loan losses, to Foreign loan losses and to the required bank capital ratio, respectively.

Decompositions are computed at the posterior mode of the estimated parameters.

The variance shares are shown for the variables listed above Cols. (1)-(12). Cols. (1)-(2): US and EA GDP; Cols. (3)-(4): US and EA consumption; Cols. (5)-(6): US and EA investment; Cols. (7)-(8): US and EA employment; Cols. (9)-(10): US and EA loans; Col. (11): bank capital ratio; Col. (12): Loan rate spread.

$4 \gamma \phi^{\prime \prime}$ : a 1 percentage point increase in the bank capital ratio lowers the lending rate spread by $4 \gamma \phi^{\prime \prime}$ percentage points.

LML: log marginal likelihood 
Table 5. Baseline model with independent shocks: dynamic responses to innovations

\begin{tabular}{|c|c|c|c|c|c|c|c|c|c|c|c|}
\hline \multirow[b]{2}{*}{ Horizon } & GDP & \multicolumn{2}{|c|}{ Consumption } & \multicolumn{2}{|c|}{ Investment. } & \multicolumn{2}{|c|}{ Employmen } & \multicolumn{2}{|c|}{ L....oans } & \multirow{2}{*}{$\begin{array}{c}\text { Bank Cap. } \\
\text { Ratio }\end{array}$} & \multirow{2}{*}{$\begin{array}{l}\text { Loan } \\
\text { Sprea }\end{array}$} \\
\hline & US EA & & EA" & US & EA' & & EA" & US & EA" & & \\
\hline & (1) (2) & (3) & (4) & (5) & (6) & (7) & (8) & (9) & $(10)$ & (11) & $(12)$ \\
\hline \multicolumn{12}{|c|}{ (a) US TFP shock (1\%) } \\
\hline 0 & $1.36-0.21$ & 1.01 & 0.10 & 1.88 & 0.11 & 0.50 & -0.29 & 0.04 & 0.03 & -0.36 & 0.06 \\
\hline 4 & $1.20-0.16$ & 0.99 & 0.09 & 1.46 & 0.15 & 0.36 & -0.23 & 0.10 & 0.11 & -1.36 & 0.28 \\
\hline 20 & $0.93-0.07$ & 0.93 & 0.06 & 0.88 & 0.20 & 0.16 & -0.11 & 0.06 & 0.26 & -2.01 & 0.41 \\
\hline \multicolumn{12}{|c|}{ (b) US investment efficiency shock (1\%) } \\
\hline 0 & $0.10 \quad 0.28$ & -0.07 & -0.14 & 2.74 & -0.48 & 0.14 & 0.39 & 0.27 & -0.06 & -0.77 & 0.23 \\
\hline 4 & 0.130 .02 & 0.04 & -0.04 & 0.93 & -0.22 & 0.09 & 0.05 & 0.92 & -0.08 & -2.07 & 0.46 \\
\hline 20 & $0.05-0.05$ & 0.07 & 0.00 & -0.21 & 0.02 & -0.01 & -0.06 & 0.83 & -0.01 & -0.41 & 0.09 \\
\hline \multicolumn{12}{|c|}{ (c) US government purchases shock (1\%) } \\
\hline 0 & $0.05 \quad 0.04$ & -0.03 & -0.02 & -0.04 & -0.06 & 0.07 & 0.05 & -0.01 & -0.01 & 0.08 & 0.00 \\
\hline 4 & $0.01-0.00$ & -0.01 & -0.00 & 0.01 & -0.01 & 0.01 & -0.00 & 0.00 & 0.00 & 0.13 & -0.03 \\
\hline 20 & $0.00-0.00$ & -0.00 & -0.00 & 0.00 & -0.00 & 0.00 & -0.00 & 0.00 & 0.01 & 0.05 & -0.01 \\
\hline \multicolumn{12}{|c|}{ (d) US labor supply shock (1\%) } \\
\hline 0 & -1.020 .20 & -0.67 & -0.10 & -1.34 & -0.15 & -1.44 & 0.28 & -0.01 & -0.03 & 0.27 & -0.04 \\
\hline 4 & $\begin{array}{ll}-0.85 & 0.14\end{array}$ & -0.65 & -0.08 & -0.96 & -0.17 & -1.16 & 0.20 & -0.01 & -0.11 & 1.02 & -0.20 \\
\hline 20 & $-0.40-0.02$ & -0.49 & -0.03 & -0.25 & -0.17 & -0.46 & 0.00 & 0.25 & -0.33 & 1.23 & -0.25 \\
\hline \multicolumn{12}{|c|}{ (e) US loan loss shock (1\% of steady state quarterly GDP) } \\
\hline 0 & $-0.10-0.12$ & 0.06 & 0.01 & -0.57 & -0.60 & -0.14 & -0.17 & -0.51 & -0.03 & -14.96 & 3.17 \\
\hline 4 & $-0.09-0.12$ & 0.04 & -0.01 & -0.50 & -0.52 & -0.12 & -0.15 & -1.53 & -0.12 & -37.15 & 7.88 \\
\hline 20 & $-0.03-0.05$ & 0.00 & -0.06 & -0.09 & -0.09 & -0.00 & -0.02 & -2.01 & -0.16 & -21.14 & 4.48 \\
\hline \multicolumn{12}{|c|}{ (f) EA loan loss shock (1\% of steady state quarterly GDP) } \\
\hline 0 & $-0.14-0.18$ & 0.01 & 0.10 & -0.81 & -0.86 & -0.20 & -0.25 & -0.07 & -0.32 & -14.49 & 3.07 \\
\hline 4 & $-0.15-0.18$ & -0.02 & 0.07 & -0.77 & -0.80 & -0.18 & -0.23 & -0.34 & -1.16 & -45.27 & 9.60 \\
\hline 20 & $-0.07-0.08$ & -0.08 & -0.00 & -0.20 & -0.19 & -0.02 & -0.04 & -0.77 & -1.85 & -37.23 & 7.90 \\
\hline \multicolumn{12}{|c|}{ (g) Shock to required bank capital ratio (1 percentage point) } \\
\hline 0 & $-0.10-0.11$ & 0.03 & 0.03 & -0.54 & -0.53 & -0.14 & -0.14 & -0.05 & -0.03 & 0.13 & 22.33 \\
\hline 4 & $-0.02-0.03$ & -0.01 & -0.01 & -0.10 & -0.09 & -0.02 & -0.02 & -0.01 & 0.04 & 15.40 & 10.62 \\
\hline 20 & $0.04 \quad 0.05$ & 0.00 & -0.00 & 0.18 & 0.19 & 0.04 & 0.06 & 0.28 & 0.25 & 19.81 & -2.13 \\
\hline
\end{tabular}

Note: The Table shows dynamic responses to exogenous shocks, after 0, 4 and 20 quarters (see left-most column labeled 'Horizon'), of the variables listed at the top of the Table. The responses are computed at the posterior mode of the estimated parameters. In each case, an isolated innovation is considered, assuming that all other exogenous innovations are zero. Panel (a): 1\% innovation to Home TFP $(\theta)$; Panel (b): $1 \%$ innovation to US investment efficiency ( $\Xi$ ); Panel (c): $1 \%$ innovation to government purchases $(G)$; Panel (d): $1 \%$ innovation to US labor supply preference parameter $\left(\Psi^{N}\right)$; Panel (e): innovation to Home loan loss $(\Delta)$ worth $1 \%$ of steady state quarterly GDP; Panel (f) innovation to Foreign loan loss $\left(\Delta^{*}\right)$ worth $1 \%$ of steady state quarterly GDP; Panel (g) innovation that raises required bank capital ratio $(\gamma)$ by 1 percentage point. Cols. (1)-(2): Responses of US and EA GDP; Cols. (3)-(4): US and EA consumption; Cols. (5)-(6): US and EA investment; Cols. (7)-(8): US and EA employment; Cols. (9)-(10): US and EA loans; Col. (11): bank capital ratio; Col. (12): Loan rate spread. Responses of the bank capital ratio are in basis points. Responses of the loan spread are in basis points per annum. Other responses are in percentage points of steady state values. 

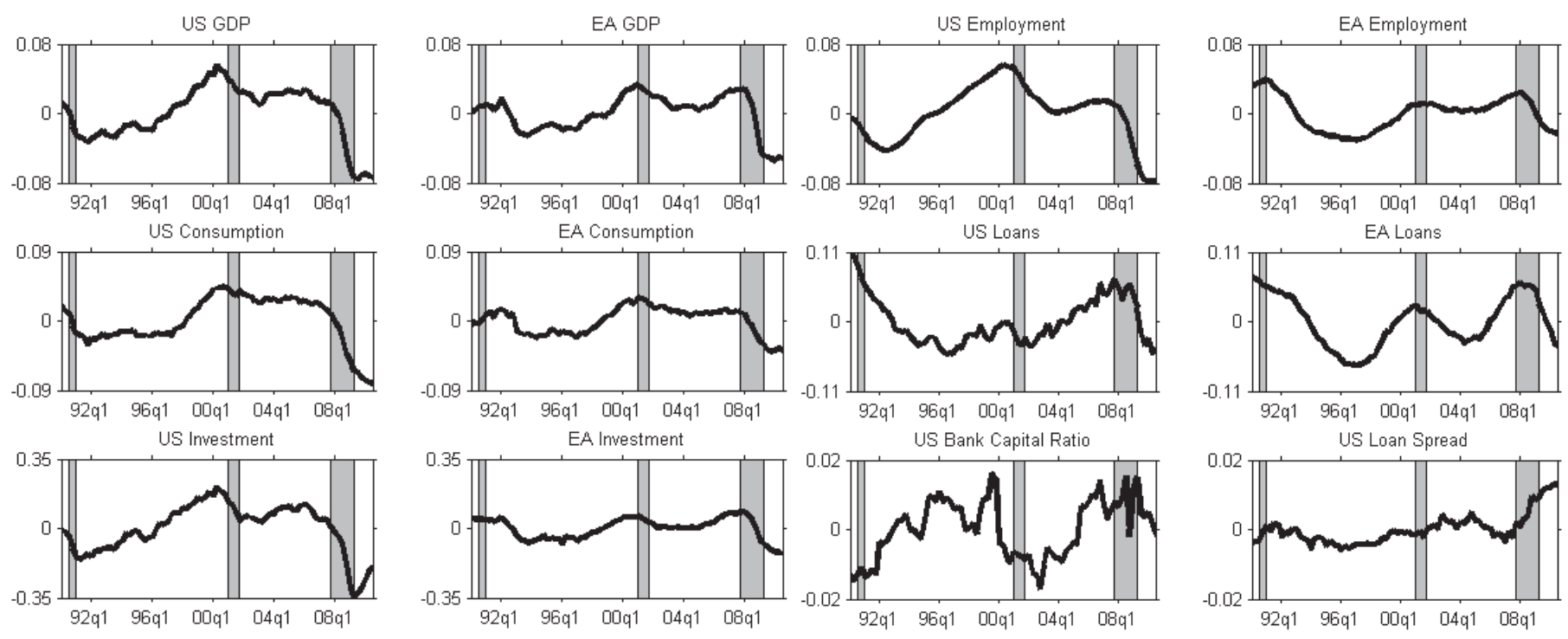

Fig. 1. Time series used in estimation

Note: The Figure shows the US and Euro Area (EA) time series (1990q1-2010q3) used in estimation. 'Loans' represent total credit by US commercial banks and EA Monetary Financial Institutions (MFI). The 'US bank capital ratio' is the capital ratio of US commercial banks. Bank capital ratio and loan spread (p.a.) are demeaned. Other variables are logged and detrended. Shaded areas indicate US recessions (NBER dates).

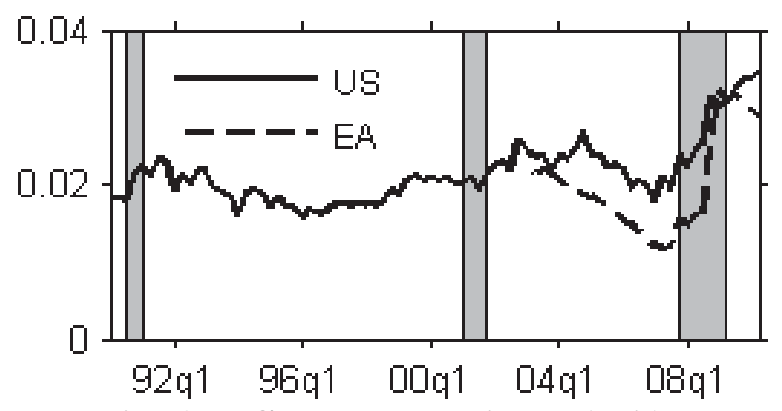

\section{Fig. 2. US and Euro Area (EA) loan rate spreads}

Note: Loan spreads (p.a.) are not demeaned.

Sample period for US (EA) loan spread:

1990q1-2010q3 (2003q1-2010q3)

Shaded areas: US recessions (NBER dates).
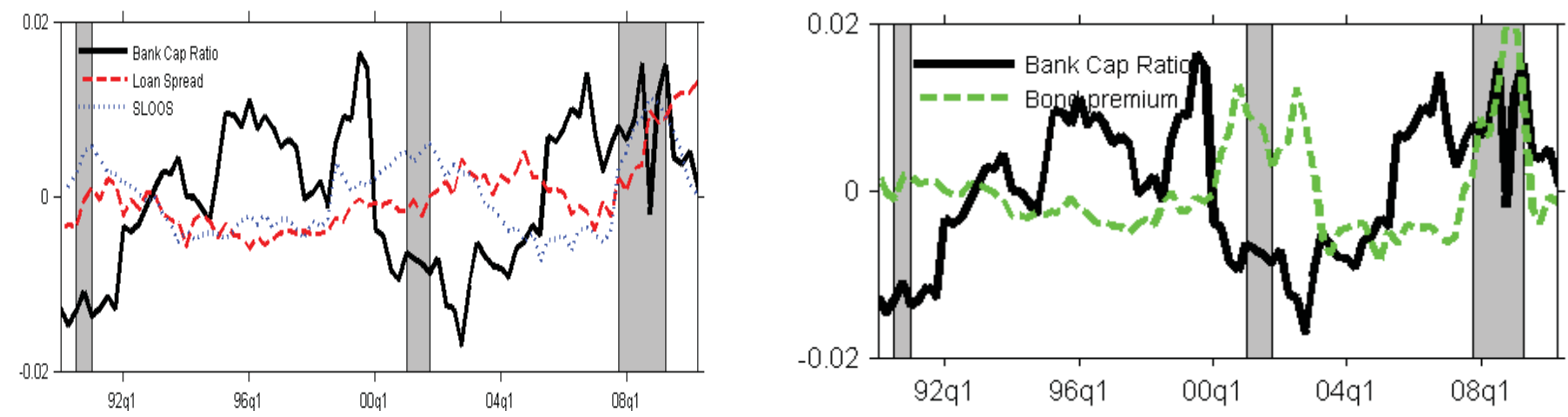

Fig. 3. US bank capital, US loan spreads and US excess bond premium

Note: In both panels, the solid line shows the demeaned US bank capital ratio. The left panel also plots the demeaned baseline US loan spread (dashed line) and the demeaned net percentage of US banks increasing spread, from Survey of Senior Loan Officers Opinion Survey (dotted line). (The SLOOS series is scaled so that its standard deviation equals that of the baseline loan spread.) The right panel plots the demeaned US excess commercial bond premium of Gilchrist and Zakrajsek, 2011a (dashed line). Sample period: 1990q1-2010q3. Shaded areas: US recessions (NBER dates). 


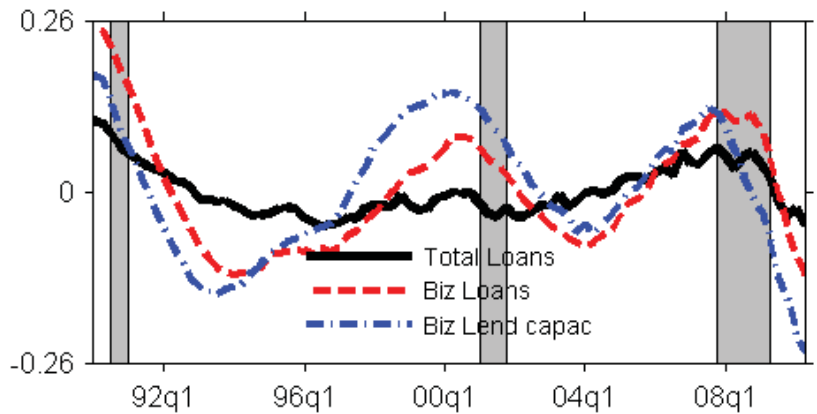

Fig. 4. US commercial banks: total loans, business loans and business lending capacity

Note: The solid line shows total US bank credit (baseline measure); dashed line: business lending; dashed-dotted line: US business lending capacity (Gilchrist and Zakrajsek (2011b). All series are linearly detrended in log form. Sample period: 1990q1-2010q3.

Shaded areas: US recessions (NBER dates).

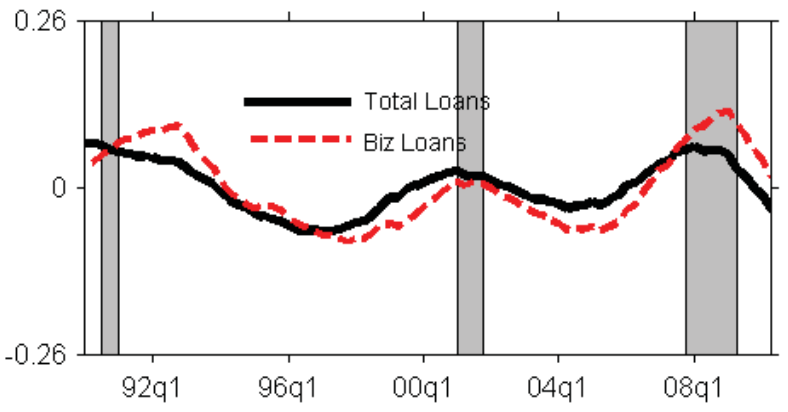

Figure 5. EA banks: total loans and business loans Note: The solid line shows total EA bank credit (baseline measure); dashed line: loans to non-financial corporations. Both series are linearly detrended in log form. Sample period: 1990q1-2010q3. Shaded areas: US recessions (NBER dates). 
Figure 6. Historical decompositions, model with independent shocks (baseline specification)
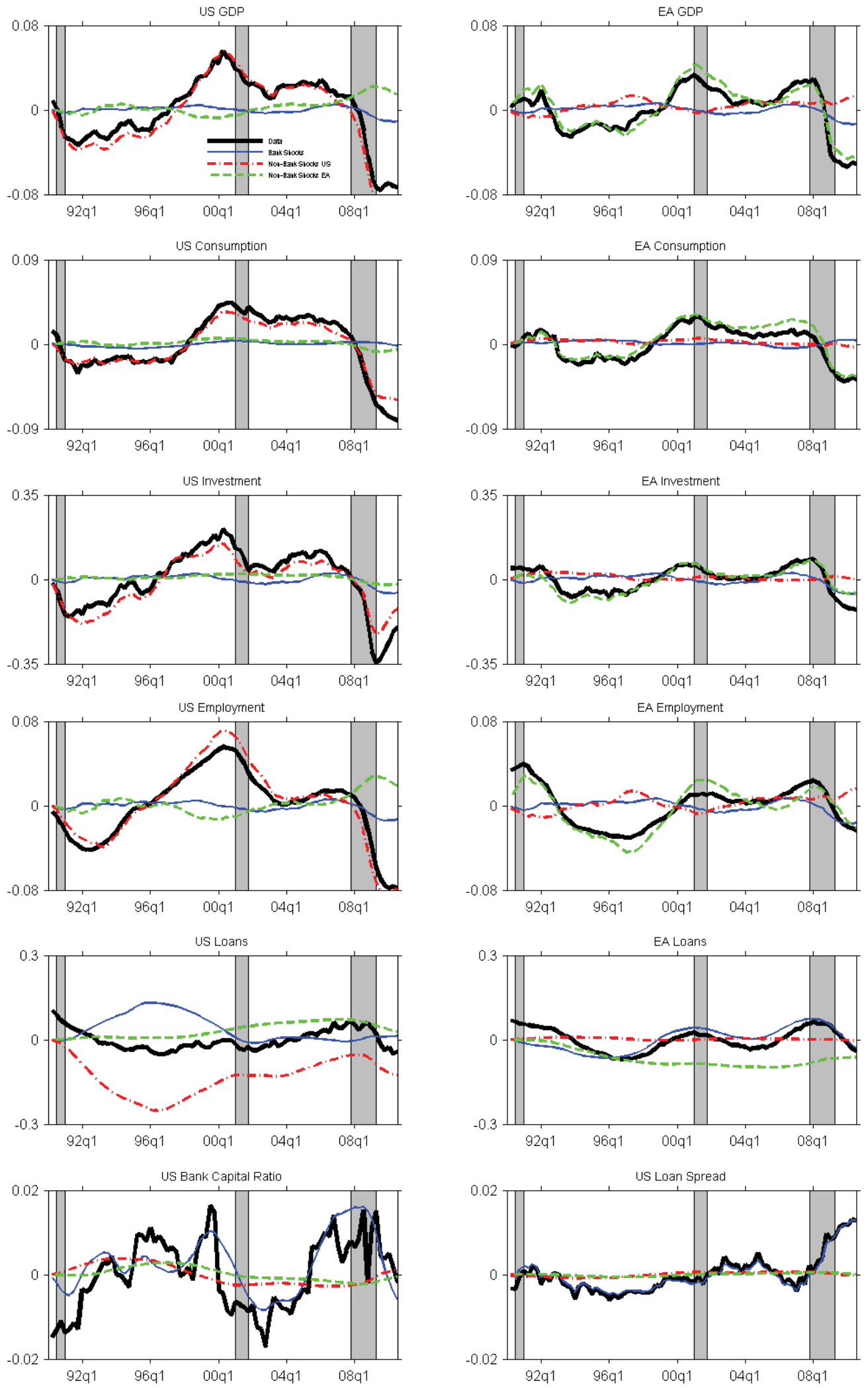

Note: Based on the baseline model with independent shocks (using posterior mode of estimated parameters), the Figure shows the historical contributions of banking shocks (thin solid lines), US non-banking shocks (dashed-dotted lines), Euro Area (EA) non-banking shocks (dashed lines) to historical series, 1990q2-2010q3 (thick solid lines). The historical bank capital ratio and loan rate spread series (р.а.) are demeaned, the other historical series are linearly detrended in log form. Shaded areas: US recessions (NBER dates). 
Figure 7. Historical decompositions, model with correlated shocks
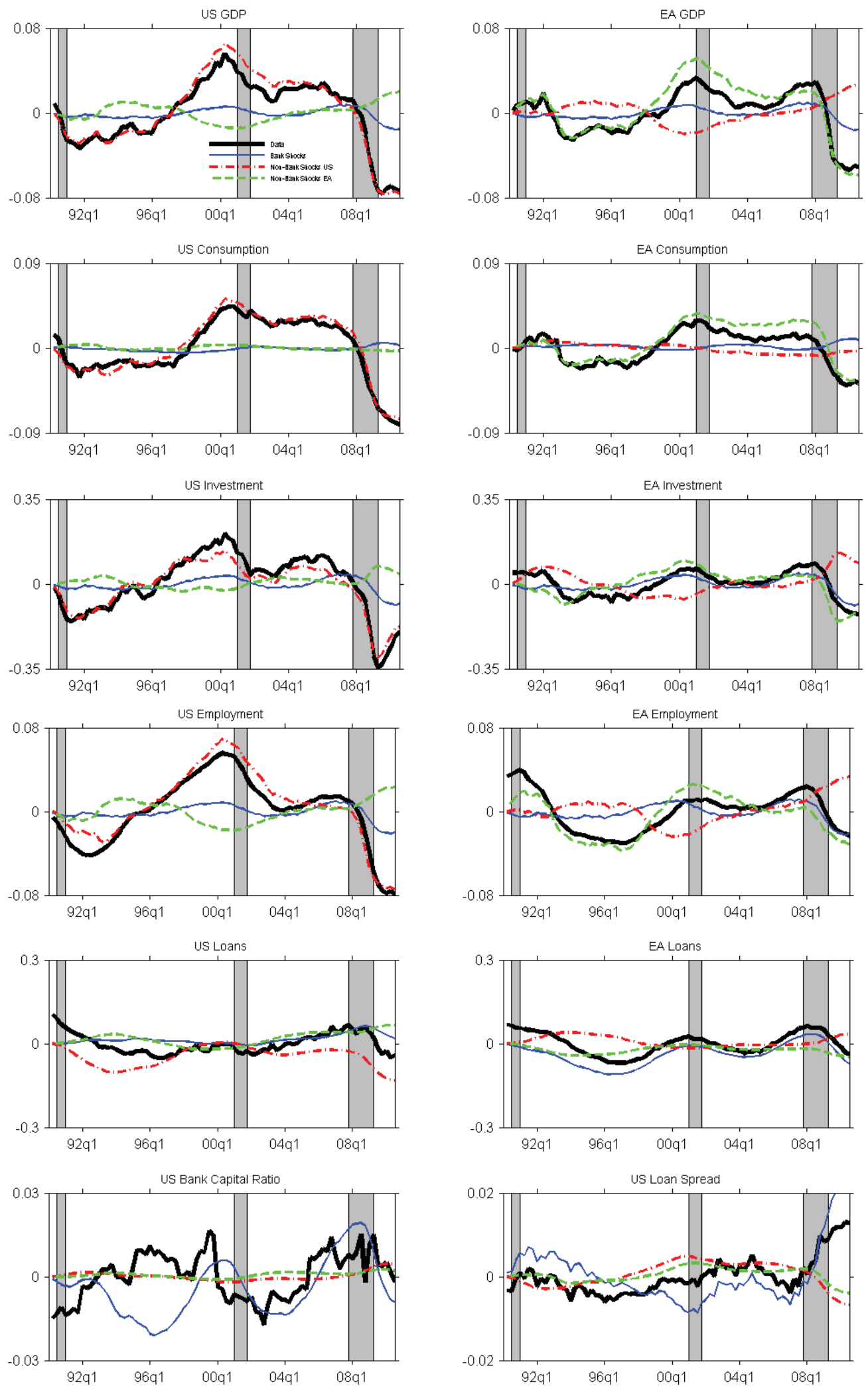

Note: Based on the model variant with correlated shocks (posterior mode of estimated parameters), the Figure shows the historical contributions of banking shocks (thin solid lines), US non-banking shocks (dashed-dotted lines), Euro Area (EA) nonbanking shocks (dashed lines) to historical series, 1990q2-2010q3 (thick solid lines). The historical bank capital ratio and loan rate spread series (р.a.) are demeaned, the other historical series are linearly detrended in log form. Shaded areas: US recessions (NBER dates). 